\title{
Hydrogeochemistry, Geothermometry, and Genesis of the Hot Springs in the Simao Basin in Southwestern China
}

\author{
Yuqi Zhang, ${ }^{1}$ Xun Zhou $\mathbb{D}^{1,}{ }^{1,2}$ Haisheng Liu, ${ }^{1}$ Mingxiao Yu, ${ }^{1}$ Kuo Hai, ${ }^{1}$ Mengru Tan, ${ }^{1}$ \\ and Dongxue Huo \\ ${ }^{1}$ School of Water Resources and Environment, China University of Geosciences (Beijing), Beijing 100083, China \\ ${ }^{2}$ MOE Key Laboratory of Groundwater Circulation and Environmental Evolution, China University of Geosciences (Beijing), \\ Beijing 100083, China
}

Correspondence should be addressed to Xun Zhou; zhouxun@cugb.edu.cn

Received 11 May 2019; Revised 8 June 2019; Accepted 12 June 2019; Published 15 July 2019

Academic Editor: Paola Cianfarra

Copyright () 2019 Yuqi Zhang et al. This is an open access article distributed under the Creative Commons Attribution License, which permits unrestricted use, distribution, and reproduction in any medium, provided the original work is properly cited.

\begin{abstract}
In the Simao Basin in southwest China widely occur red beds of poor permeability. Nevertheless, more than 100 springs exist in the basin, some of which are hot springs with varying temperature. Hot springs contain abundant information on hydrogeochemical processes and groundwater circulation. In this study, hydrochemical and isotopic analyses and mixed models are used to examine the sources of recharge, heat, and solutes of the hot springs to better understand the subsurface processes and formation mechanisms of different hot springs in the basin. Three types of springs are found in the Simao Basin: springs of $\mathrm{HCO}_{3}-\mathrm{Na}$ type occur in the metamorphic rocks, springs of $\mathrm{HCO}_{3} \mathrm{Ca}(\mathrm{Mg})$ and $\mathrm{Cl}-\mathrm{HCO}_{3}-\mathrm{Na}-\mathrm{Ca}$ types in the carbonate rocks, and springs of $\mathrm{Cl}\left(\mathrm{SO}_{4}\right)-\mathrm{SO}_{4}(\mathrm{Cl})-\mathrm{HCO}_{3}-\mathrm{Na}(\mathrm{Ca})$ type in the red beds. Data of $\delta^{2} \mathrm{H}$ and $\delta^{18} \mathrm{O}$ indicate that the hot springs in the Simao Basin are meteoric in origin. Incongruent dissolution is the dominant process affecting the chemical compositions of the spring waters. The hydrochemical constituents of the hot springs in the metamorphic rocks, carbonate rocks, and red beds are influenced by the weathering of albite and the dissolution of carbonate, gypsum, anhydrite, and halite. The geothermal waters are mixed with shallow cold waters in their ascending processes, and the mixing ratios of cold water range from $58 \%$ to $94 \%$. Due to the effect of mixing, the reservoir temperatures $\left(51^{\circ} \mathrm{C}-127^{\circ} \mathrm{C}\right)$ calculated with the quartz geothermometer are regarded as the minimum reservoir temperatures. More reliable reservoir temperatures $\left(91^{\circ} \mathrm{C}-132^{\circ} \mathrm{C}\right)$ are estimated with the fixed-Al method. The following mechanisms contribute to the formation of hot springs in the Simao Basin: the groundwater receives recharge from infiltration of precipitation and undergoes deep circulation, during which groundwater is heated by heat flow and incongruently dissolves the subsurface minerals and emerges in the form of hot springs along the permeable fracture or fault zones.
\end{abstract}

\section{Introduction}

Hot springs are commonly of meteoric origin, and they are heated by heat flow and undergo water-rock interactions during deep circulation. The hydrochemical characteristics of hot springs are conducive to reveal information on geothermal reservoirs and thermal groundwater circulation and may provide insights into the potential of geothermal resources and the subsurface transport of substance. Springs occur in various types and in varying quantities in the Simao Basin (the southern half of the Lanping-Simao Basin) covered mostly by red beds of relatively low permeability. Previous studies in the Simao Basin mainly focused on the occurrence and formation of salt mineral resources. Systematic studies of the hot springs in the basin were seldom examined. It is of important significance to examine the evolution of the hydrogeochemical processes and the genesis of the hot springs, which can provide support for hydrogeological exploration, geothermal resource development, and mineral resource prospecting in the basin.

The origin, reservoir temperature, hydrochemical evolution, and formation of hot springs are the focuses of many researches. Studies of stable isotopes play a significant role in hydrogeological investigations of both thermal and nonthermal groundwaters because the isotopes carry a record of fluid source and processes [1]. Zhou et al. [2] 
systematically analyzed the $\delta^{2} \mathrm{H}$ and $\delta^{18} \mathrm{O}$ of 90 samples of 68 representative hot springs or geothermal wells in China, revealing that almost all the thermal groundwater in China is of meteoric in origin except the subsurface hot brines in the Sichuan Basin. Koeniger et al. [3] studied the stable isotopes of 70 precipitation samples and 1000 spring water samples from the Anti-Lebanon Mountains in western Syria and showed that the spring waters originated from the precipitation of the Mediterranean Sea and estimated recharge catchment altitudes to infer areas of a high vulnerability through pollution. The ratios of ions in spring waters are commonly used to analyze the water-rock interactions in groundwater circulation. Hershey et al. [4] examined the relationships of cations and anions in different combinations to gain information on water quantity and quality of 16 regional springs in the Great Basin in western United States and identified regionally sourced springs that had not been previously recognized. Yaguchi et al. [5] analyzed the chemical and isotopic compositions of the hot spring waters around the Miocene Kofu granitic complex surrounding the Kofu Basin in Japan, suggesting that the major ions are controlled by the montmorillonization of plagioclase, cation exchange reaction of $\mathrm{Na}$-montmorillonite and precipitation of calcite, and the $\mathrm{SO}_{4}$ of springs in granite areas is derived from the oxidation of sulfides while that of springs in volcanic areas is derived from the dissolution of anhydrite. Different types of geothermometers are used to evaluate temperatures for the hydrothermal potentialities of deep reservoirs. Pang and Reed [6] pioneered a new approach named fixed-Al using the SOLVEQ program to restore the equilibrium status of a low-moderate temperature geothermal field and selected some typical lowmoderate temperature geothermal systems in the world to estimate reservoir temperatures. Sonney and Vuataz [7] tested the applicability of geothermometers in deep aquifers of low temperature from northern Switzerland, summarized geological settings and temperature ranges for different chemical and isotopic geothermometers, and plotted the measured temperatures at depth with the corresponding geotemperature curves to evaluate the accuracy and applicability of various geothermometers. The mixing models that can indicate the original temperatures of hot groundwater are commonly used as a reference for the reservoir temperatures [8]. The evolution and formation of spring waters can provide important information on local geology and hydrogeology. Asta et al. [9] studied chemical characteristics of the low-temperature geothermal system of Panticosa (Spain) and conducted geothermometrical modeling calculations for the compositions of the hottest water (Tiberio spring) under both open and closed system conditions, suggesting that the results are consistent with the temperatures calculated with the classical geothermometers. Awaleh et al. [10] conducted detailed geochemical investigations of the cold groundwater and the most representative thermal groundwaters in the Obock area in the Republic of Djibouti, estimated the reservoir temperature through chemical and isotopic geothermometers as well as a mineral equilibrium approach, and proposed a conceptual model of the Obock beach geothermal system, revealing that the geothermal fluid is mixed in varying degrees with fresh water and cold seawater. Belhai et al. [11] summarized the formation of spring waters in northeastern Algeria, suggesting that cold precipitation infiltrated to a depth of up to $2.5 \mathrm{~km}$ and was heated by a conductive heat source, and then, the geothermal waters were mixed with shallow cold groundwater during the ascent flow to the land surface through the deep fractures. Chandrasekhar et al. [12] studied the evolution of thermal fluids along the western continental margin of India using geochemical and boron isotope characteristics and developed a conceptual model to better explain the evolution of the thermal spring waters, indicating that the meteoric water, seawater, the Deccan flood basalts, the Kaladgi sedimentary formations, and the Precambrian granites contributed to the evolution of the West Coast thermal spring waters.

A few researches on springs in the Simao Basin focused on the potassium exploration through salty and saline springs, and the origin and evolution as well as genesis of the springs were also examined. Zhang et al. [13] studied the indicators involving sylvite by detecting 11 salt spring samples in the Mengla salt-belt in the southern Simao Basin, revealing that there is a tendency for the brines to gradually concentrate from north to south and suggesting that Yanjing, Mozheng, and Nanben are the 3 most prospecting areas in the Mengla salt-belt for potassium exploration. Bo et al. [14] studied the hydrochemical and isotopic characteristics (oxygen, hydrogen, and strontium) of 21 spring waters and isotopic compositions of $\mathrm{He}$ and $\mathrm{Ne}$ in gases escaping from spring waters in the Lanping-Simao Basin, suggesting that the spring waters originate from precipitation and undergo deep circulation, and revealed that the Lanping-Simao Basin has geochemical affinities with northern Laos and Yanjing rather than with the Tengchong block. Zhang et al. [15] summarized the groundwater enrichment conditions in the red beds in the Simao Basin based on the previous studies and field investigations and illustrated the genesis of springs of deep groundwater circulation and shallow groundwater circulation, which can provide reasonable suggestions for the further development and research of springs in Yunnan Province of China.

The present study is aimed at (1) exploring the favorable factors for the emergence of hot springs in the red beds in the Simao Basin, (2) determining the sources of recharge and heat based on the hydrochemical and stable isotope data and evaluating reservoir temperatures by using both the classical geothermometers and the fixed-Al method, (3) investigating the evolution processes of geothermal waters by examining the relationships of ions in different combinations and establishing mixing models to estimate the mixing proportions of the thermal groundwater with cold waters, and (4) summarizing the formation mechanisms of different types of springs in the Simao Basin. The results of this study can provide insights into mass transport in groundwater circulation, establish the framework for the study of the geothermal system in the basin, and provide important information for the exploration and utilization of geothermal and salt resources in similar sedimentary basins in other regions. 


\section{Description of the Study Area}

2.1. Geological Setting. The Simao Basin, located in the southwest of Yunnan in China, belongs to the southern section of the Sanjiang fold system [16]. The basement rocks of the Simao Basin are composed of three sets of metamorphic rock groups (the Lancang, Wuliangshan, and Ailaoshan groups) formed in the Proterozoic-Cambrian period [17]. Because of the opening of the Paleo-Tethys Ocean during the Devonian period, muddy sandstones and carbonate rocks of a platform type mainly developed in the Simao Basin. The Indosinian movement began after the closure of the Paleo-Tethys Ocean during the Late Permian, leading to the uplifting of the entire Simao Basin. With the opening of the Meso-Tethys Ocean in the Middle Triassic, seawater intruded into the basin from east and west sides and developed towards the central part, resulting in argillaceous carbonate deposition in the basin. Significant differentiation of the basement topography occurred in the basin, forming prototypes of 8 depressions and uplifts [16]. With the opening of the Neo-Tethys Ocean in the Middle Jurassic, seawater invaded again from the west and thick red and variegated clastic rocks with salt-bearing formations deposited in the basin. From the Late Jurassic to the end of the Early Cretaceous, the rocks of the Simao Basin were generally uplifted and denuded due to the Yanshan Movement. During the Late Cretaceous, the Neo-Tethys Ocean gradually closed and the Simao Basin evolved into a continental basin with the regression. In the early Paleocene, a continuous dry paleoclimate led to the extensive deposits of gypsum and thickly bedded halite with occasional sylvite [18]. Since the Eocene, the Himalayan movement has resulted in a few uplifts and nappe structures, and some intermountain basins were formed in the basin [16].

A series of deep NW-SE trending faults were developed in the Simao Basin, including the Lancangjiang deep fault, Minle-Mengyang fault, Wuliangshan fault, Amojiang fault, and Ailaoshan fault from west to east (Figure 1(a)). The Lancangjiang deep fault $\left(\mathrm{F}_{1}\right)$ is the western boundary of the Simao Basin, which extends along the Lancangjiang River valley in a roughly $\mathrm{S}-\mathrm{N}$ direction, showing the characteristic of ductile strike-slip shear. The Ailaoshan deep fault $\left(\mathrm{F}_{2}\right)$ is the eastern boundary of the basin, which extends along the west side of the Ailao Mountain in a NW-SE direction, showing complex characteristics of thrust nappe and ductile strike-slip shear. The northern part of the Minle-Mengyang fault $\left(\mathrm{F}_{3}\right)$ is roughly parallel to the Lancangjiang deep fault, trending in the S-N direction, and its southern part extends along the line from Mengyang to Mengban in the NW-SE direction. The NNW trending Wuliangshan fault $\left(\mathrm{F}_{4}\right)$ is located in the central basin, which is also called the central axis fault. It is composed of three secondary faults: the Zhenyuan-Puwen fault $\left(\mathrm{F}_{4}{ }^{1}\right)$, the Pu'er fault $\left(\mathrm{F}_{4}{ }^{2}\right)$, and the Mohei fault $\left(\mathrm{F}_{4}{ }^{3}\right)$ from west to east. These three branch faults were destroyed into several segments by a series of later faults in the NE direction near Zhengdong. The Amojiang Fault $\left(\mathrm{F}_{5}\right)$ is located in the eastern Simao Basin and extends along the Amojiang River in the NNW direction, which was formed in the Late Varissian and was strongly active during the Indosinian-Yanshanian period. The above faults that are inclined at large angles converge in the Jingdong area and gradually spread out southward, showing the characteristic of an arc protruding to the west. It is believed that these faults suffered similar stress during the last tectonic movement, forming the present tectonic pattern and appearance under the conditions of intense compression in the west and blocking in the east [17].

The Simao Basin belongs to the stratigraphic region of Eastern Tibet-Western Yunnan. The basin is underlain by strata ranging in age from Proterozoic to Cenozoic (Figure 1(a)). The outcropping strata are related to the division of tectonic units of the basin. The thick Mesozoic and Cenozoic red beds occur in the depression areas in the basin. Due to the later denudation, the Upper and Middle Paleozoic limestones outcrop in the central block uplifts and the marginal belt uplifts in the basin, with sporadic occurrences of the Lower Paleozoic rocks. The Proterozoic metamorphic rocks occur in the form of long stripes along the Ailaoshan fault zone and appear sporadically on the east side of the Lancangiiang fault. The Simao Basin is divided into east and west regions by the Amojiang fault. There are obvious differences between the two regions in strata of the Pre-Ordovician and Jurassic but little difference in strata of Cretaceous and Quaternary. Detailed stratigraphic information in the Simao Basin is given in Table 1.

2.2. Description of Hot Springs in the Simao Basin. Most parts of the Simao Basin are covered by red beds, with sporadic occurrences of limestones. The metamorphic rocks of the Lancang Group outcrop in the west part of the basin, and a belt of metamorphic rocks of the Ailaoshan Group appears on the eastern side. In this study, 12 water samples from 8 hot springs (numbered from north to south) collected in the Simao Basin are classified into three types according to the rock type. (1) The springs emerge in the Ailaoshan metamorphic rocks on the eastern edge of the basin, including the Wana hot spring (S1) with a smell of $\mathrm{H}_{2} \mathrm{~S}$ and discharge of about $10 \mathrm{~L} / \mathrm{s}$, whose outlet is $8 \mathrm{~m}$ above the nearby river. (2) Springs exist in the carbonate rocks, including the Ximenlongtan spring (S3), Xiling hot springs (S4-1 and S4-2), and Nanni hot springs (S8-1 and S8-2) (S3 was built as a water supply well), with discharge of $25-35 \mathrm{~L} / \mathrm{s}$. (3) Springs occur in red beds which mainly consist of salt-bearing mudstones and sandstones, including the Qingping hot springs (S2-1 and S2-2), Manzhongtian hot spring (S5), Zhengdong hot springs (S6-1 and S6-2), and Erguanzhai hot spring (S7), with discharge of 4-10 L/s. There are small-scale travertine deposition near S2-1, S2-2, S7, S8-1, and S8-2.

\section{Sampling and Analysis Methods}

Field works were conducted in July 2016 and August 2017. Spring water samples S1, S3, S4-1, S4-2, S5, S6-1, S6-2, S7, S8-1, and S8-2 and a rainwater sample SR were collected in 2016, and samples S2-1 and S2-2, in 2017. Temperature, $\mathrm{pH}$, Eh, and free $\mathrm{CO}_{2}$ were measured in the field, and water samples were collected and stored in $550 \mathrm{~mL}$ plastic bottles 


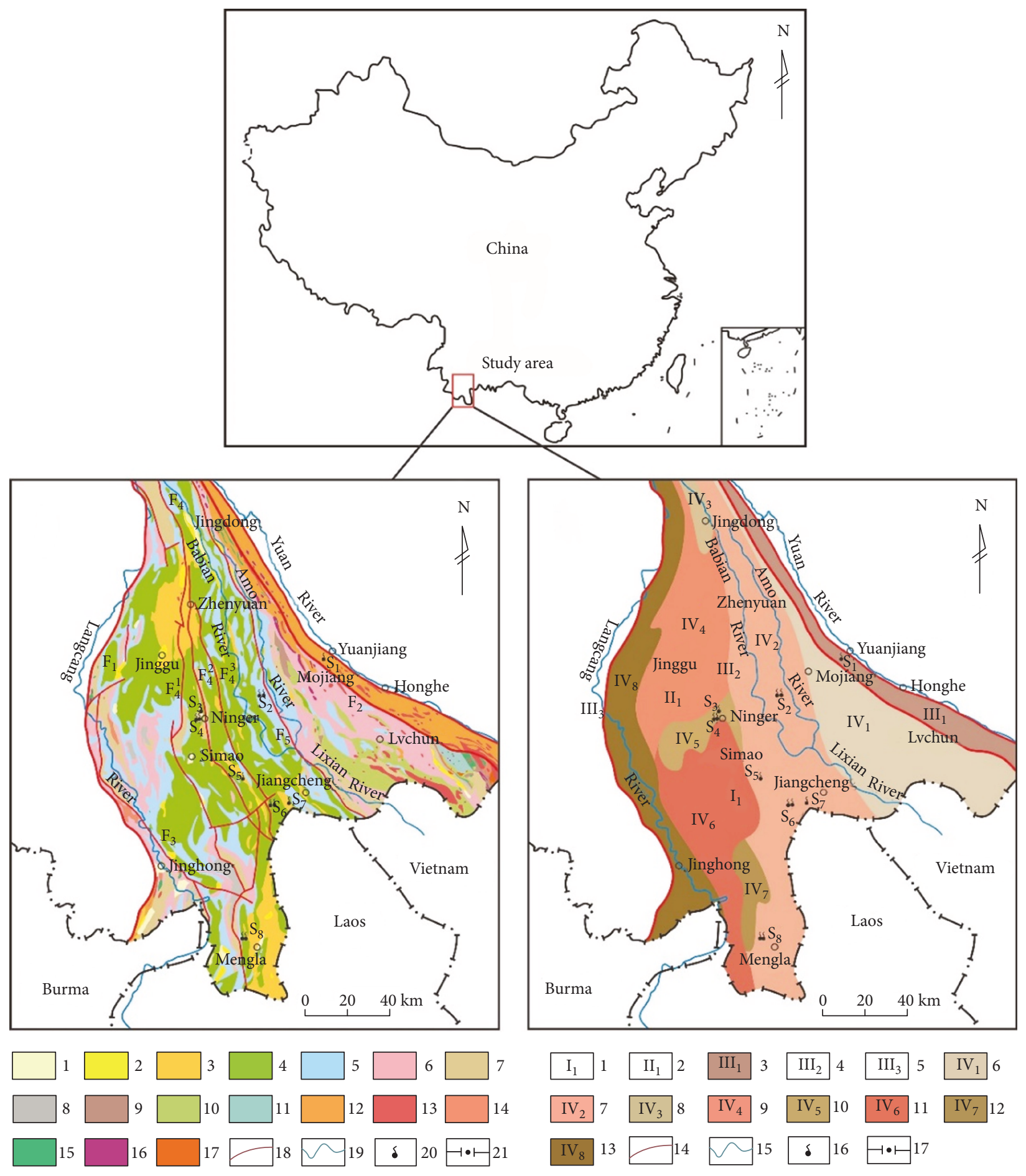

(a)

(b)

FIGURE 1: Geological map in the Simao Basin (modified from [16]). (a) Occurrence of strata and faults in the Simao Basin: 1: Quaternary gravel and clay; 2: Neogene mudstone and fine sandstone; 3: Paleogene salt-bearing gompholite and sandstone; 4: Cretaceous quartz sandstone, siltstone, and mudstone; 5: Jurassic mudstone, siltstone, and gypsum; 6: Triassic limestone, shale, mudstone, and siltstone; 7: Permian limestone, mudstone, siltstone, and tuff; 8: Carboniferous limestone, shale, and tuff; 9: Devonian marl, mudstone, shale, and siltstone; 10: Silurian silicolites, shale, quartz sandstone, and siltstone; 11: Ordovician clastic rocks with limestone; 12: Proterozoic gneiss, granulite, schist, and marble; 13: granite; 14: quartz monzonite; 15: gabbro; 16: magnesian ultramafic rock; 17: quartz syenite; 18: fault; 19: river; 20: spring; 21: international boundary. (b) Tectonic division in the Simao Basin: 1: Sanjiang fold system; 2: LancangjiangAilaoshan fold belt; 3: Ailaoshan uplift; 4: Simao rift valley; 5: Lancangjiang uplift; 6: Mojiang margin uplift; 7: Jiangcheng depression; 8: Wuliangshan uplift; 9: Jinggu depression; 10: Pu'er-Dehua uplift; 11: Dadugang depression; 12: Mengyuan uplift; 13: Jinghong margin uplift; 14: fault; 15: river; 16: spring; 17: international boundary. 


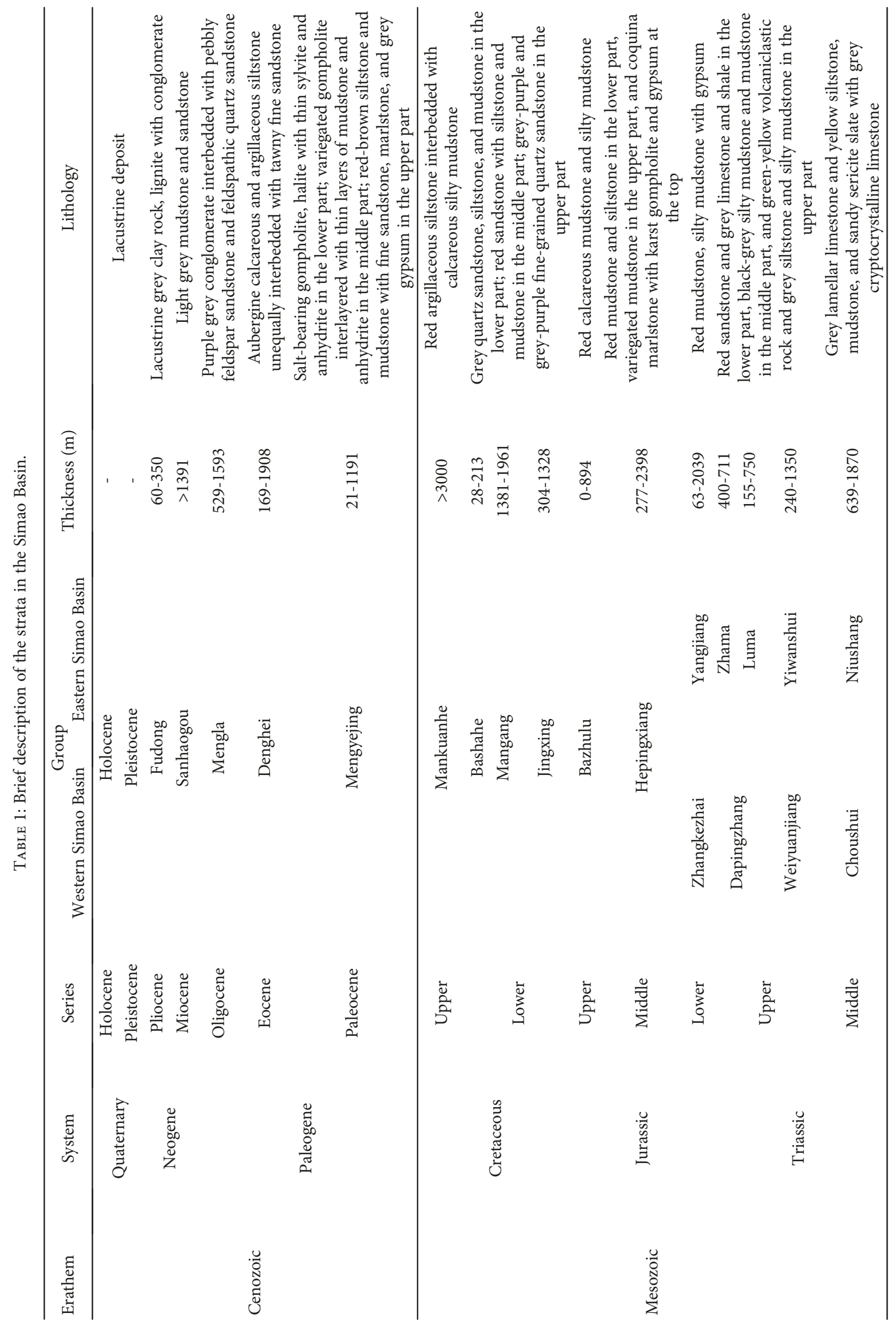




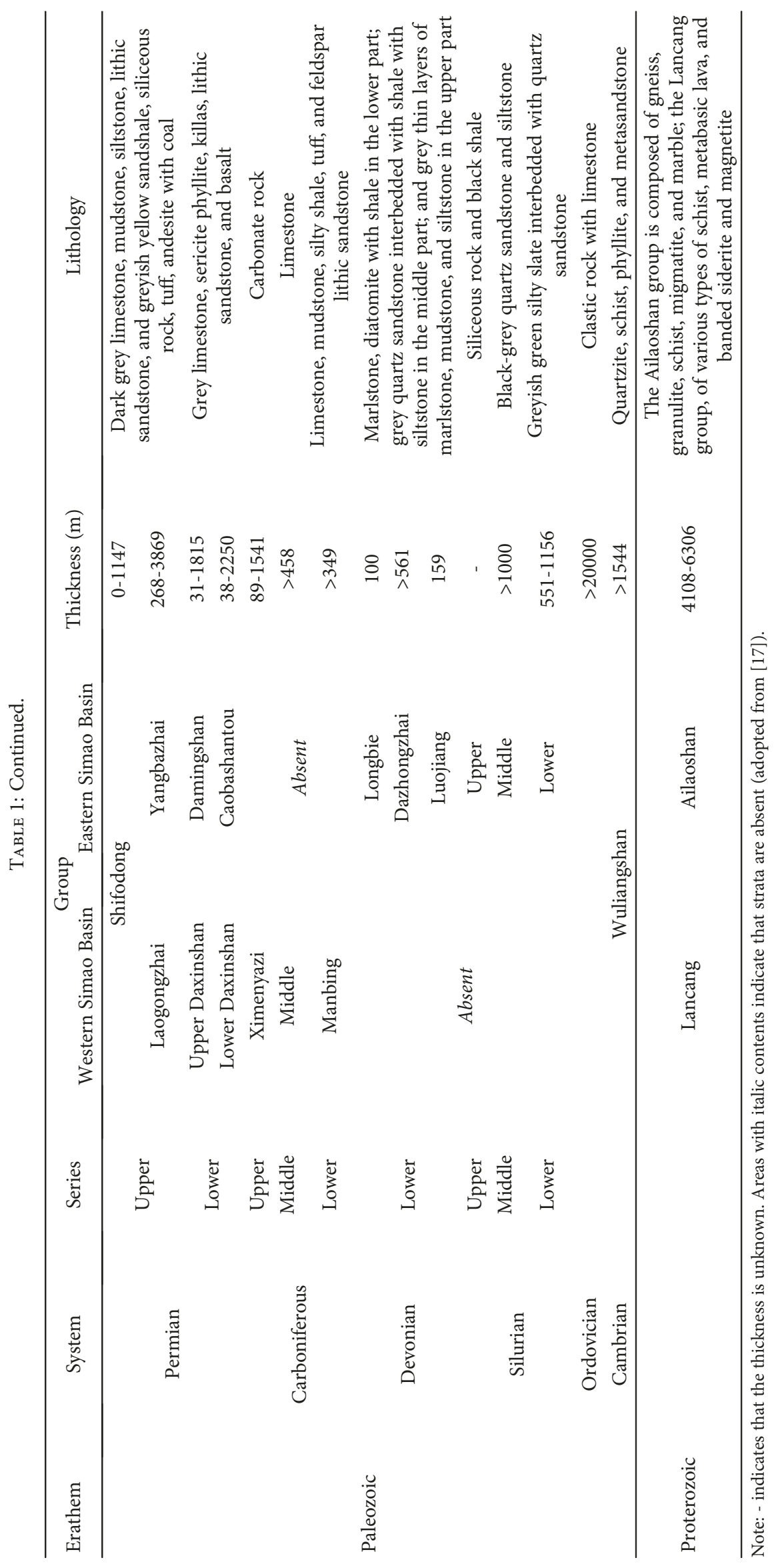


for hydrochemical analyses. The hydrochemical and stable isotope analyses were conducted in the Analytical Center of Beijing Research Institute of Uranium Geology. According to the Examination Methods for Groundwater Quality (DZ/T 0064-1993) and China National Standard Examination Methods for Drinking Water (GB/T5750-2006), K and $\mathrm{Na}$ were tested by flame atomic absorption spectrometry; $\mathrm{Cl}, \mathrm{F}, \mathrm{SO}_{4}$, and $\mathrm{NO}_{3}$, by ion chromatography; $\mathrm{Li}, \mathrm{Sr}, \mathrm{Rb}, \mathrm{Fe}$, $\mathrm{Zn}, \mathrm{Ba}$, and $\mathrm{Mn}$, by inductively coupled plasma-mass spectrometry; $\mathrm{Ca}, \mathrm{Mg}$, and total hardness, by the volumetric method (EDTA titrimetry); $\mathrm{HCO}_{3}$ and total alkalinity, by the volumetric method ( $\mathrm{HCl}$ titrimetry); and total acidity, by the volumetric method ( $\mathrm{NaOH}$ titrimetry). The $\delta^{2} \mathrm{H}$ and $\delta^{18} \mathrm{O}$ were analyzed according to the Geological Mineral Industry Standards for Zinc Reduction of Hydrogen Isotopes in Water (DZ/T 0184.19-1997) and the Carbon DioxideWater Equilibrium Method for Oxygen Isotopes in Natural Water (DZ/T 0184.21-1997). The detections of $\mathrm{Br}, \mathrm{SiO}_{2}$ (aq) (analyzed as $\mathrm{H}_{2} \mathrm{SiO}_{3}$ ), $\mathrm{B}$ (analyzed as $\mathrm{HBO}_{2}$ ), ${ }^{226} \mathrm{Ra}$, and ${ }^{222} \mathrm{Rn}$ were conducted at the Laboratory of Beijing Institute of Hydrogeology and Engineering Geology according to China National Standard Examination Methods for Drinking Water (GB/T5750-2006) and China National Standard Examination Methods for Drinking Natural Mineral Water (GB/T 8538-2008). Br was measured by ion chromatography; $\mathrm{H}_{2} \mathrm{SiO}_{3}$ and $\mathrm{HBO}_{2}$, by a spectrophotometer. A reliability test was carried out to validate the hydrochemical results of the 12 water samples using anion-cation balance, and the errors range from $0.03 \%$ to $12.94 \%$, among which the errors of S2-1, S2-2, and S4-2 are 10.93\%, 9.94\%, and $12.94 \%$, respectively, since these spring waters contain relatively high contents of $\mathrm{NH}_{4}$ [19]. The hydrochemical analyses of the water samples in the Simao Basin are listed in Table 2.

\section{Results}

Temperatures of the spring waters in the Simao Basin range from 29.7 to $77.2^{\circ} \mathrm{C}$, and the $\mathrm{pH}$ values, from 5.6 to 7.1 , indicate that the hot waters are weak acid-neutral and the geothermal systems are of low-to-moderate temperature. TDS of the water samples range from 0.35 to $3.21 \mathrm{~g} / \mathrm{L}$, and the TDS of the springs occurring in the red beds $(1.41-3.21 \mathrm{~g} / \mathrm{L})$ are higher than those of the springs in the metamorphic rocks $(0.47 \mathrm{~g} / \mathrm{L})$ and carbonate rocks (0.35-1.05 g/L). A Piper diagram (Figure 2) shows that the major ions in the hot spring in the metamorphic rocks (S1) are dominated by $\mathrm{HCO}_{3}$ and $\mathrm{Na}$, and those in hot springs in the carbonate rocks (S3, S4-1, and $\mathrm{S} 4-2)$ are $\mathrm{HCO}_{3}, \mathrm{Ca}$, and $\mathrm{Mg}$, while those in hot springs in the carbonate rocks (S8-1 and S8-2) are $\mathrm{Cl}$, $\mathrm{HCO}_{3}, \mathrm{Na}$, and $\mathrm{Ca}$, close to the samples in the red beds. The major ions in most hot springs emerging in the red beds (S5, S6-1, S6-2, and $\mathrm{S} 7$ ) are $\mathrm{Cl}\left(\mathrm{SO}_{4}\right)$ and $\mathrm{Na}$, in addition to samples $\mathrm{S} 2-1$ and $\mathrm{S} 2-2$, which are predominated by $\mathrm{Na}$ and $\mathrm{HCO}_{3}$ and tend to approach sample $\mathrm{S} 1$ in Figure 2. A Schoeller diagram (Figure 3 ) of the water samples shows three groups of ions. The contents of $\mathrm{Ca}$ and $\mathrm{Mg}$ are the lowest in the spring water existing in the metamorphic rocks, while those of $\mathrm{K}$ and $\mathrm{Na}$ are the lowest in spring waters in the carbonate rocks (except samples S8-1 and S8-2). The content of $\mathrm{HCO}_{3}$ is abundant in all the three types of spring waters. The contents of $\mathrm{Cl}$ and $\mathrm{SO}_{4}$ are significantly higher in spring waters in the red beds (including samples S8-1 and $\mathrm{S} 8-2$ ), and the $\mathrm{SO}_{4}$ content shows an obvious difference. $\mathrm{SO}_{4}$ contents are higher in samples S5, S6-1, S6-2, and S7 but lower in S2-1, S2-2, S8-1, and S8-2. The F content is most abundant in the spring water in the metamorphic rocks $(16.7 \mathrm{mg} / \mathrm{L})$, followed by the spring waters in the carbonate rocks $(0.39-0.95 \mathrm{mg} / \mathrm{L})$. Except for a small amount of $\mathrm{F}$ in samples S2-1 and S2-2 (0.29-0.32 mg/L), F was not detected in other springs occurring in the red beds (including samples S8-1 and S8-2). Moreover, the contents of trace elements ( $\mathrm{Sr}, \mathrm{Li}, \mathrm{Fe}, \mathrm{Rb}, \mathrm{Zn}, \mathrm{Ba}$, and $\mathrm{Mn}$ ) in the spring waters in the Simao Basin are quite different, in which the contents of $\mathrm{Sr}, \mathrm{Li}$, and $\mathrm{Fe}$ are slightly higher than those of other trace elements, with values of $0.15-3.02 \mathrm{mg} / \mathrm{L}, 0.47-0.0037 \mathrm{mg} / \mathrm{L}$, and $0.33-0.053 \mathrm{mg} / \mathrm{L}$, respectively. The content of $\mathrm{Sr}$ is the highest in the hot springs in the red beds (including samples S8-1 and S8-2), while the Li content is the lowest in the hot springs in the carbonate rocks (except samples S8-1 and S8-2). The content of $\mathrm{Fe}(0.053-0.33 \mathrm{mg} / \mathrm{L})$ is similar among the three types of spring waters. It is worth noting that the hydrochemical characteristics of springs S8-1 and S8-2 in the carbonate rocks are similar to those of springs in the red beds.

\section{Discussion}

5.1. Recharge Source of the Hot Springs. As components of water molecules, stable hydrogen and oxygen isotopes are useful indicators of groundwater studies, which provide information on water origin, recharge and migration pathways, fault and fracture permeability to fluids, and so on [20]. The stable isotopes are commonly used to distinguish among meteoric, marine, and magmatic origins of spring water. The results of stable isotope analyses of the spring waters for the Simao Basin are presented in Table 2. The values of $\delta^{2} \mathrm{H}$ and $\delta^{18} \mathrm{O}$ range from $-86.9 \%$ to $-56.8 \%$ and from $-12.8 \%$ o to $-6.8 \%$, respectively. The stable isotope compositions of the spring waters and rainwater are shown in Figure 4 together with the global meteoric water line (GMWL) $\left(\delta^{2} \mathrm{H}=8 \delta^{18} \mathrm{O}+10\right)$ [21] and the local meteoric water line (LMWL) $\left(\delta^{2} \mathrm{H}=7.51 \delta^{18} \mathrm{O}-0.48\right)$ [22]. The measured meteoric water line on the diurnal time scale at Simao was selected as LMWL, with a slope slightly less than that of GMWL. All the data points fall close to the GMWL and LMWL, indicating that the spring waters in the Simao Basin are of meteoric origin. The modern rainfall data point lies on LMWL, and the spring water samples (except S2-2) lie slightly below the GMWL and LMWL. The slight ${ }^{18} \mathrm{O}$ shift in these water samples is related to the oxygen isotope exchange between geothermal groundwater and surrounding rocks, especially the carbonate rocks. There is no significant change in $\delta^{2} \mathrm{H}$ in these water samples due to the low ${ }^{2} \mathrm{H}$ content in the rocks. Thus, the range in $\delta^{2} \mathrm{H}$ content reflects the initial composition of the influent water undergoing deep circulation and the impact of the mixing with shallow cold water as the water ascends [23]. There is slight deviation to 


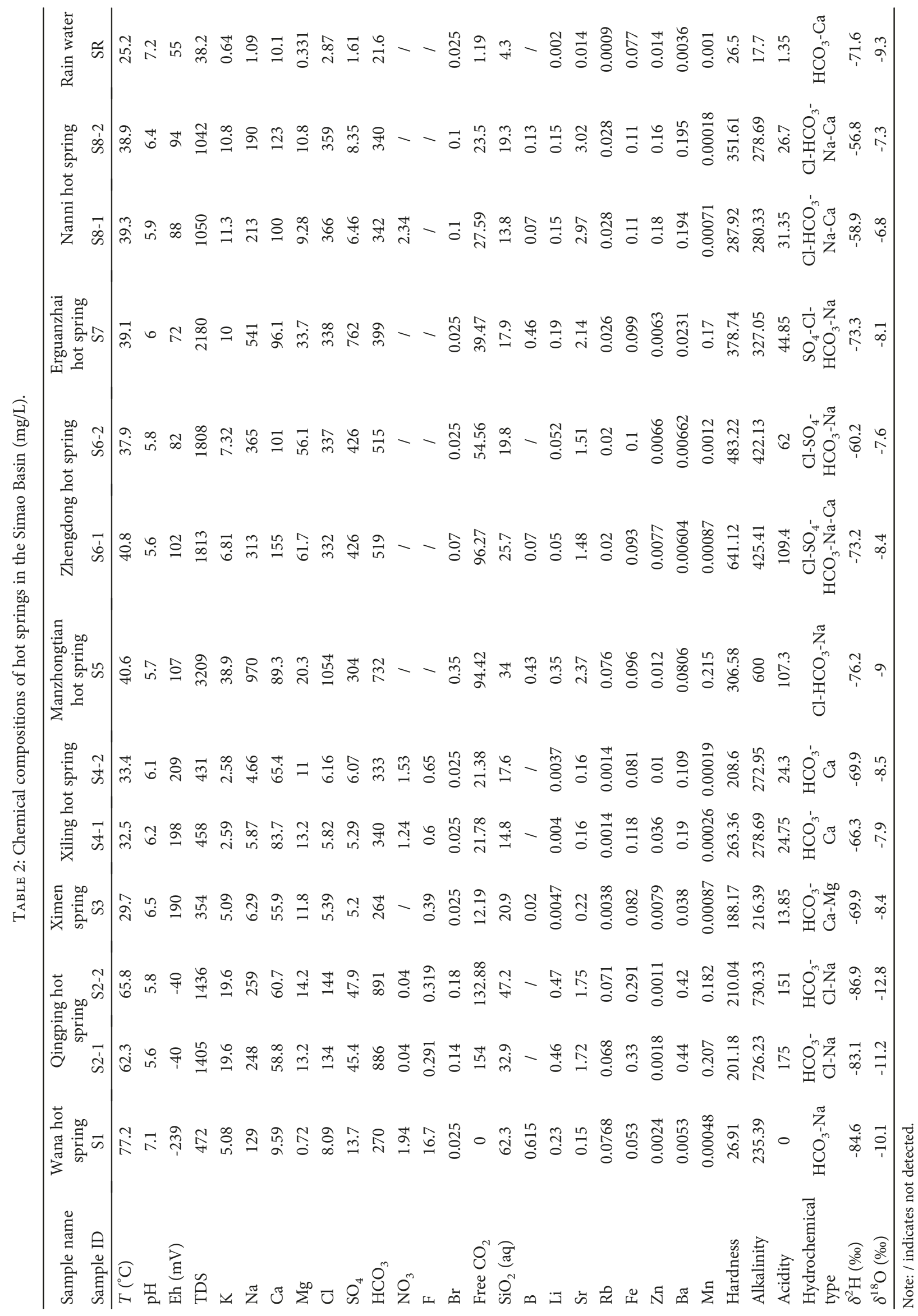




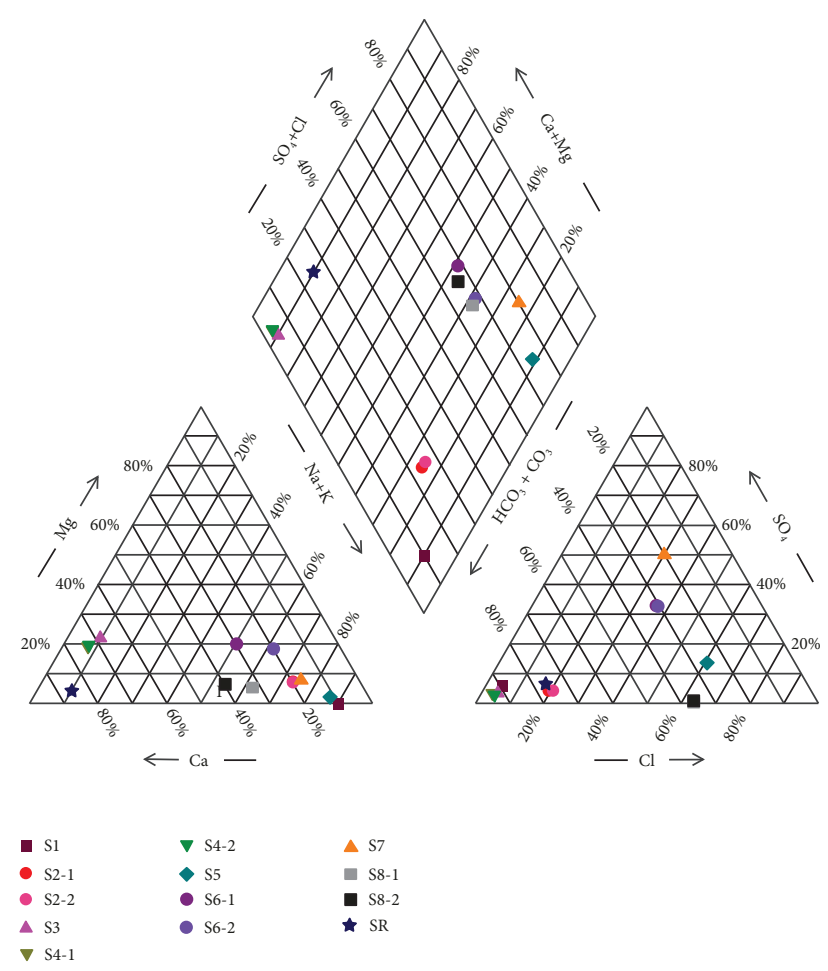

FIGURE 2: Piper diagram showing the hot spring water samples in the Simao Basin.

the left of the water samples S2-1 and S2-2 relative to other water samples. As the spring water ascends to the land surface, travertine is deposited with $\mathrm{CO}_{2}$ escape. The heavier isotope is preferentially fractionated into $\mathrm{CO}_{2}$, resulting in ${ }^{18} \mathrm{O}$ depletion in the water [23]. However, previous studies have shown that this process is suitable for low-temperature conditions [24], while the temperatures of springs S2-1 and S2-2 are relatively high with an average value of $64^{\circ} \mathrm{C}$. Therefore, it is not clear whether the slight left shift of sample points S2-1 and S2-2 can be explained by the above reaction, which remains to be further explored.

5.2. Source of Dissolved Ions in the Hot Spring Waters. The Gibbs diagram is a semilogarithmic coordinate diagram that can intuitively reflect the mechanisms (atmospheric precipitation, water-rock interaction, and the evaporationcrystallization process) controlling major components in natural waters (surface water and groundwater) [25]. Figure 5 shows the weight ratios of $\mathrm{Na} /(\mathrm{Na}+\mathrm{Ca})$ and $\mathrm{Cl} /\left(\mathrm{Cl}+\mathrm{HCO}_{3}\right)$ against TDS. Three distinct parts including atmospheric precipitation dominance (APD), rock weathering dominance (RWD), and evaporation-crystallization dominance (ECD) areas make up the segments in the Gibbs diagram. In Figure 5, both the weight ratios of $\mathrm{Na} /(\mathrm{Na}+\mathrm{Ca})$ and $\mathrm{Cl} /\left(\mathrm{Cl}+\mathrm{HCO}_{3}\right)$ of the samples $\mathrm{S} 3, \mathrm{~S} 4-1$, and $\mathrm{S} 4-2$ in the carbonate rocks are less than 0.5, and the TDS is medium, indicating that the solutes of these spring waters are controlled by water-rock interactions. The original rocks of regional metamorphic rocks are intermediate-basic magmatic rocks, the main mineral of which is albite [17]. Hence, the weight ratio of $\mathrm{Cl} /\left(\mathrm{Cl}+\mathrm{HCO}_{3}\right)$ of the sample $\mathrm{S} 1$ is less than 0.5 and that of $\mathrm{Na} /(\mathrm{Na}+\mathrm{Ca})$ is greater than 0.5 , also suggesting that the components of the sample $\mathrm{S} 1$ are mainly derived from the weathering of rocks. The $\mathrm{Na} /(\mathrm{Na}+\mathrm{Ca})$ ratios of samples S2-1, S2-2, S5, S6-1, S6-2, and S7 in the red beds and S8-1 and S8-2 in the carbonate rocks range from 0.57 to 0.91 , and the $\mathrm{Cl} /\left(\mathrm{Cl}+\mathrm{HCO}_{3}\right)$ ratios range from 0.21 to 0.71. It can be seen in Figure 5 that these spring points fall in the rock dominance area and move slightly towards the upper right of the Gibbs diagram, seemingly affected by evaporative-crystallization. However, those springs exist in a relatively humid environment that is less likely to evaporate and crystallize. In this study, this movement is due to the dissolution of the halite which results in an increase in the concentrations of $\mathrm{Na}$ and $\mathrm{Cl}$ in the spring waters. Therefore, the solutes of all studied spring waters in the Simao Basin are likely to dominate by rocks.

5.2.1. Ions in Spring Waters in the Metamorphic Rocks. In the study area, spring S1 occurs in the Ailaoshan high-grade metamorphic belt and is dominated by $\mathrm{Na}$ and $\mathrm{HCO}_{3}$ with low TDS of $0.47 \mathrm{mg} / \mathrm{L}$. Moreover, the data point S1 plots close to the $1: 1$ line in Figure 6(a), indicating that the quality of the water sample of $\mathrm{S} 1$ is influenced by the weathering of albite. The precipitation rich in $\mathrm{CO}_{2}$ infiltrates into the deep metamorphic rocks and reacts with the albite as follows [5]:

$$
\begin{aligned}
6 \mathrm{CO}_{2}+6 \mathrm{H}_{2} \mathrm{O} \rightarrow 6 \mathrm{H}^{+}+6 \mathrm{HCO}_{3}^{-} \\
7 \mathrm{NaAlSi}_{3} \mathrm{O}_{8}+6 \mathrm{H}^{+}+20 \mathrm{H}_{2} \mathrm{O} \rightarrow 3 \mathrm{Na}_{0.33} \mathrm{Al}_{2.33} \mathrm{Si}_{3.67} \mathrm{O}_{10}(\mathrm{OH})_{2} \\
+6 \mathrm{Na}^{+}+10 \mathrm{H}_{4} \mathrm{SiO}_{4}
\end{aligned}
$$

The concentration of $\mathrm{SO}_{4}$ in sample $\mathrm{S} 1$ is $13.7 \mathrm{mg} / \mathrm{L}$, while that in the collected rainwater is only $1.61 \mathrm{mg} / \mathrm{L}$, so it seems that $\mathrm{SO}_{4}$ in spring water $\mathrm{S} 1$ is not derived from precipitation. The Ailaoshan metamorphic rocks contain certain pyrite [17] which is easily oxidized under oxygen-rich conditions close to the surface [26]. Therefore, it is supposed that the $\mathrm{SO}_{4}$ in the hot spring water $\mathrm{S} 1$ may originate from the pyrite oxidation:

$$
\mathrm{FeS}_{2}+15 / 4 \mathrm{O}_{2}+7 / 2 \mathrm{H}_{2} \mathrm{O} \rightarrow \mathrm{Fe}(\mathrm{OH})_{3}+2 \mathrm{SO}_{4}{ }^{2-}+4 \mathrm{H}^{+}
$$

The $\mathrm{pH}$ of sample $\mathrm{S} 1$ is 7.1, which is more alkaline than that of other water samples. It is inferred that the $\mathrm{H}$ released by the oxidation of pyrite was consumed by the interaction with albite, as shown in reaction (2). To some extent, the pyrite oxidation promotes the weathering of albite [17]. Besides, the sample $\mathrm{S} 1$ has a slight $\mathrm{H}_{2} \mathrm{~S}$ odor possible due to $\mathrm{SO}_{4}$ reduction to $\mathrm{H}_{2} \mathrm{~S}$ in an anaerobic subsurface environment.

5.2.2. Ions in Spring Waters in the Carbonate Rocks. Spring samples S3, S4-1, and S4-2 are in the limestones near Ninger and are dominated by $\mathrm{Ca}, \mathrm{Mg}$, and $\mathrm{HCO}_{3}$ with low TDS ranging from 0.3 to $0.5 \mathrm{mg} / \mathrm{L}$, while samples S8-1 and S8-2 are in the limestones in the Nanni area and are dominated by $\mathrm{Na}, \mathrm{Ca}, \mathrm{Cl}$, and $\mathrm{HCO}_{3}$ with a little bit higher TDS ranging from 1.04 to $1.05 \mathrm{mg} / \mathrm{L}$. This difference in hydrochemistry may be due to the different lithologies of strata in the 


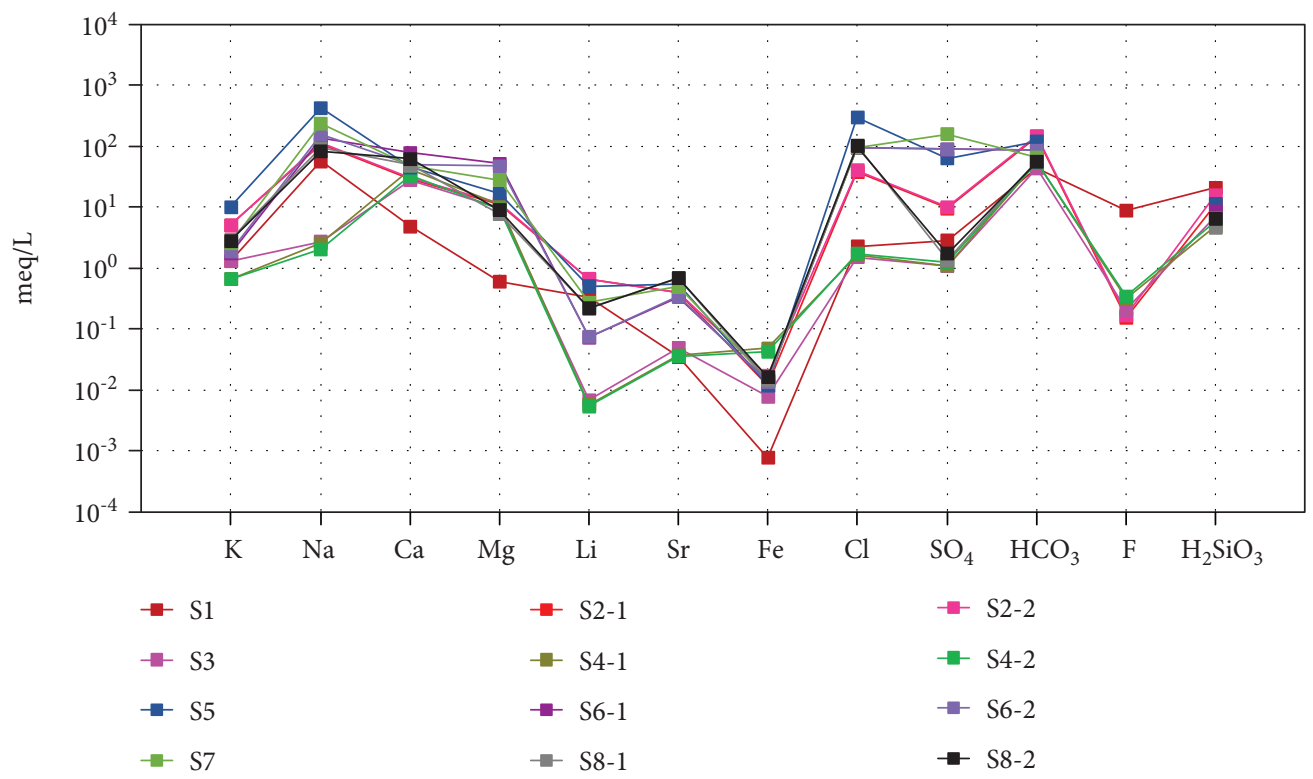

FIgURe 3: Modified Schoeller diagram showing major ion constituents of the hot spring water samples in the Simao Basin.

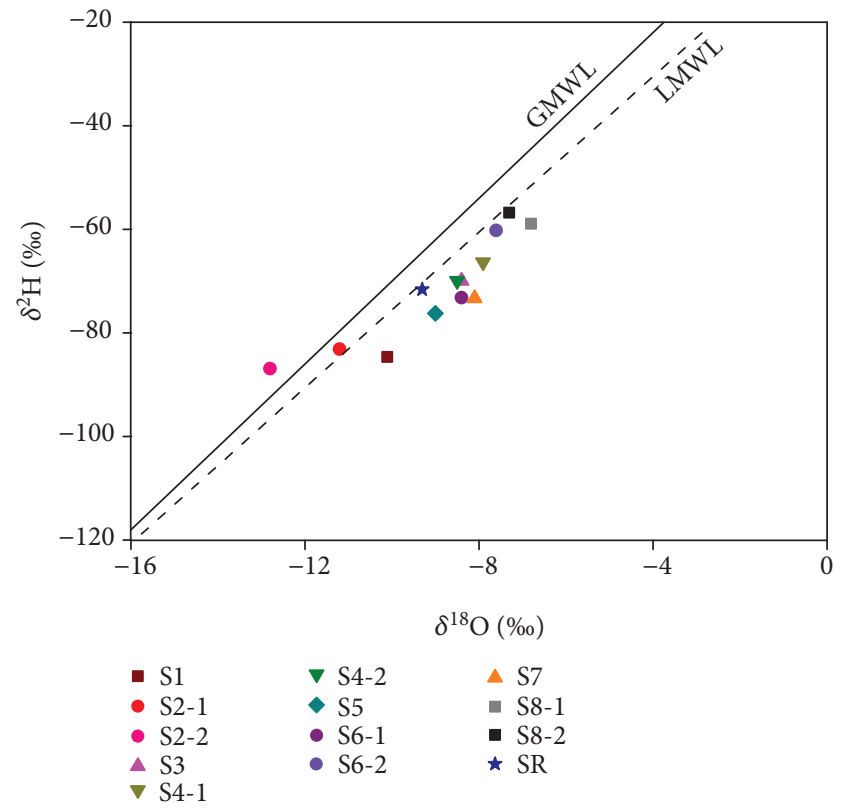

FIGURE 4: $\delta^{2} \mathrm{H}-\delta^{18} \mathrm{O}$ plot for the hot spring samples in the Simao Basin.

recharge areas. In Figure 6(b), data points of S3, S4-1, S4-2, S8-1, and S8-2 all fall near the 1:1 line, indicating the contribution of incongruent dissolution of carbonate minerals (calcite and dolomite). This clearly reflects the interaction of meteoric water with the upper Permian limestone and dolomite sequence, which constitute the principal reservoir rocks of the Ninger and Nanni areas. The springs in the two areas show a marked difference in Figure 6(c). All the data points in the carbonate rocks plot very close to the $1: 1$ line (halite dissolution line), while the data points in Ninger fall on the bottom quarter of Figure 6(c) with less contents of $\mathrm{Na}(4.6-6.3 \mathrm{mg} / \mathrm{L})$ and $\mathrm{Cl}(5.3-6.2 \mathrm{mg} / \mathrm{L})$ and those in Nanni on the top third with more contents of $\mathrm{Na}$ $(190-213 \mathrm{mg} / \mathrm{L})$ and $\mathrm{Cl}(359-366 \mathrm{mg} / \mathrm{L})$. The small area of the exposed limestones in Nanni is of sporadic distribution, which is completely surrounded by nearby red beds. The springs in Nanni are recharged partly in the nearby red-bed zone; groundwater dissolves the halite in the salt-bearing strata along the flow path and emerges in the carbonate rocks, resulting in more contents of $\mathrm{Na}$ and $\mathrm{Cl}$ than those of $\mathrm{Ca}$ and $\mathrm{HCO}_{3}$ in the spring waters. In Figure 6(d), all the data points in the carbonate rocks are far above the $1: 1$ line (gypsum dissolution line) with lower $\mathrm{SO}_{4}$ contents (5.2-8.4 mg/L), suggesting that the process of dissolution of gypsum and anhydrite may not contribute to the source of $\mathrm{Ca}$ in those spring waters. The above discussion is also demonstrated by the mineral saturation indices (SI) in Section 5.2.5.

5.2.3. Ions in Spring Waters in the Red Beds. The red beds in the study area refer to the purple-red Jurassic, Cretaceous, and Paleogene mudstones and sandstones. There are three salinization formations in the red beds in the Simao Basin, namely, the Paleocene salt-bearing gompholite, halite with thin sylvite and anhydrite, the Upper Cretaceous gompholite interbedded with gypsum, and the Middle and Lower Jurassic gypsum and salt-bearing gompholite. As can be seen in Figure 1(a), springs S2-1 and S2-2 emerge in the Middle Jurassic mudstone and siltstone; springs S5 and S7, in the Paleocene mudstone; and springs S6-1 and S6-2, in the Lower Cretaceous sandstone and mudstone. Since all of the hot water flow through the deep Triassic carbonate rocks, the content of $\mathrm{HCO}_{3}$ is relatively high, with values ranging from 340 to $891 \mathrm{mg} / \mathrm{L}$. Figure 6(c) shows that the data points of springs in the red beds plot close to the $1: 1$ line (halite dissolution line), with higher contents of $\mathrm{Na}(190-970 \mathrm{mg} / \mathrm{L})$ and $\mathrm{Cl}(134-1054 \mathrm{mg} / \mathrm{L})$, indicating that halite dissolution is the 

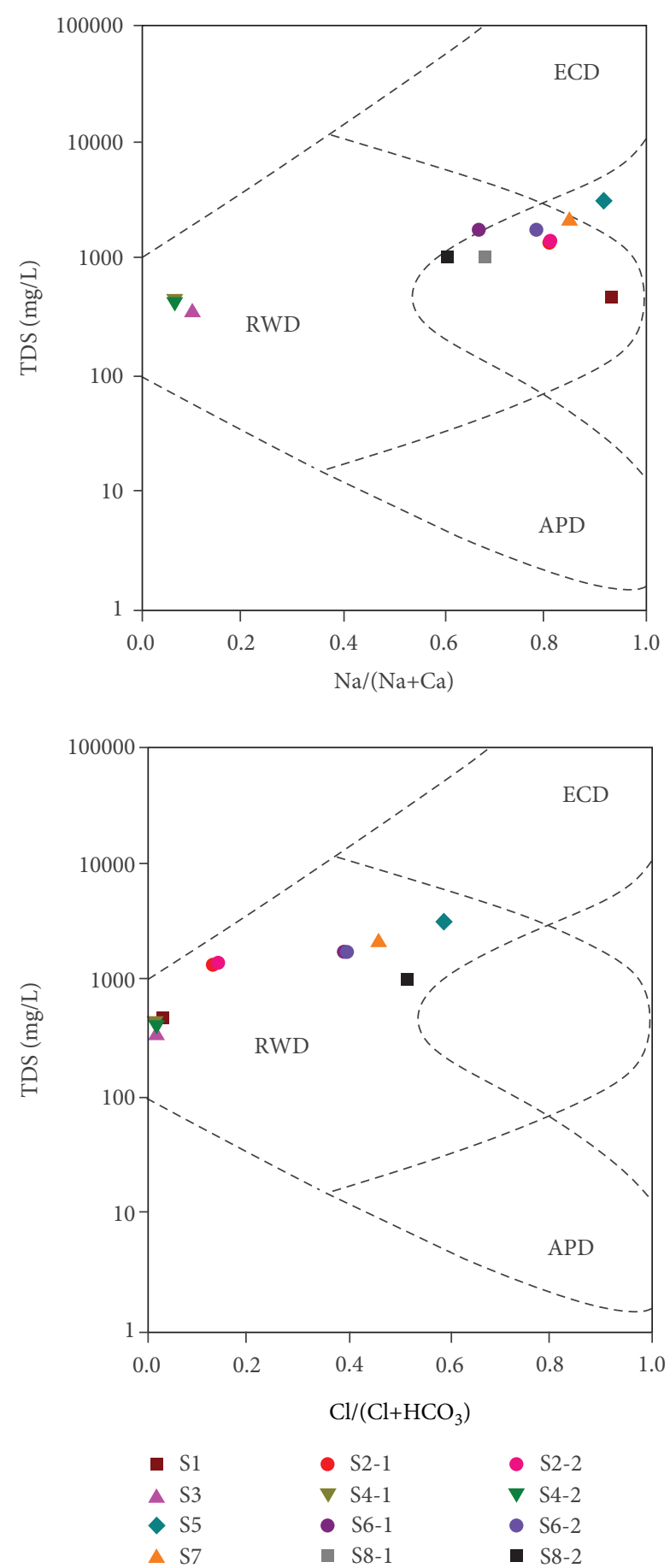

FIGURE 5: Gibbs diagram showing the hot spring water samples in the Simao Basin.

main source of ions dominating the spring hydrochemistry. In Figure 6(d), it can be seen that the data points of S5, S6-1, S6-2, and S7 fall near the 1:1 line (gypsum dissolution line), suggesting that the dissolution of gypsum and anhydrite is the main source of $\mathrm{Ca}$ and $\mathrm{SO}_{4}$. However, the contents of $\mathrm{SO}_{4}$ in water samples S2-1 and S2-2 are lower than those in other water samples, which are far exceeded by $\mathrm{Ca}$ content, indicating that these springs might undergo a long time of incongruent dissolution of the carbonate rocks.
Figures 6(c) and 6(e) show that there are excess $\mathrm{Na}$ and $\mathrm{HCO}_{3}$ or $\mathrm{SO}_{4}$ in the spring waters in the red beds. The dissolution of mirabilite may contribute to the additional $\mathrm{Na}$ and $\mathrm{SO}_{4}$ in samples $\mathrm{S} 5, \mathrm{~S} 6-1, \mathrm{~S} 6-2$, and $\mathrm{S} 7$, and the mixing with terrestrial water in the eastern Simao Basin, to the additional $\mathrm{Na}$ and $\mathrm{HCO}_{3}$ in samples S2-1 and S2-2. It is worth noting that spring waters S2-1 and S2-2 undergo circulation through the Lower and Middle Jurassic salt-bearing strata dominated by gypsum, while the $\mathrm{Ca}$ content is less relative to that of $\mathrm{Na}$, as well as $\mathrm{SO}_{4}$ relative to $\mathrm{HCO}_{3}$ and $\mathrm{Cl}$. As mentioned earlier, high content of $\mathrm{HCO}_{3}$ may be influenced by the mixing process. High content of $\mathrm{Cl}$ may be related to the unknown halite deposition in the Jurassic strata in the Simao Basin, since some salty springs of a Cl-Na type commonly emerge in the Middle Jurassic strata [16].

Figure 6(f) shows a significant difference in the milliequivalent concentration ratio of $\mathrm{Ca}+\mathrm{Mg}$ to $\mathrm{Na}+\mathrm{K}$ among spring waters of different types, suggesting different water-rock interaction processes. The ratios of springs in the red beds range from 0.1 to 1 ; those in the metamorphic rocks are less than 0.1 , and those in the carbonate rocks are much greater than 1 , ranging between 9 and 17 .

5.2.4. Trace Elements in the Hot Spring Waters. Trace elements are often used to determine the origin and genesis of groundwater because of their stability and universality [27]. The probable source of trace elements is the dissolution of marine minerals, and there is often a correlation between the trace elements and major elements. Strontium is a widely distributed trace element in nature, which mainly disperses in the sulfate, carbonate, and silicate minerals in the form of isomorphism [28]. The concentration of $\mathrm{Sr}$ in the samples ranges from 0.15 (S1) to $3.02 \mathrm{mg} / \mathrm{L}$ (S8-2), in which the contents of springs in the red beds are higher than those of springs in the metamorphic and carbonate rocks except samples S8-1and S8-2. In Figure 7, $\mathrm{Sr}$ and $\mathrm{SO}_{4}$ exhibit a good linear relationship for the majority of points, indicating that the higher contents of Sr in the spring waters in the red beds are derived from the dissolution of sulfate minerals such as anhydrite, gypsum, and celestite. Based on the lithology of the study area, the lower content of Sr in the spring water in the metamorphic rocks is mainly from the weathering of plagioclase, and those in the carbonate rocks may come from the dissolution of carbonate minerals such as calcite and strontianite. It is worth noting that water samples S8-1 and S8-2 in the carbonate rocks have the highest Sr content, suggesting the source of both sulfate minerals and carbonate minerals. Moreover, $\mathrm{CO}_{2}$ may favor the dissolution of $\mathrm{Sr}$ in carbonate minerals in the form of $\operatorname{Sr}\left(\mathrm{HCO}_{3}\right)_{2}$ [29]. The concentration of $\mathrm{Li}$ is between 0.0037 (S4-2) and $0.47 \mathrm{mg} / \mathrm{L}$ (S2-2), in which the contents of springs in the metamorphic rocks and red beds are relatively higher than those of springs in the carbonate rocks except samples S8-1and S8-2. Li is probably derived from incongruent dissolution of volcanic rocks and also occurs in evaporites and natural brines [4]. The Ailaoshan metamorphic rocks originated from a series of intermediate-basic volcano-sedimentary formations, and the red beds are typical salt-bearing formations [17]. Therefore, Li content is relatively rich in springs in the 

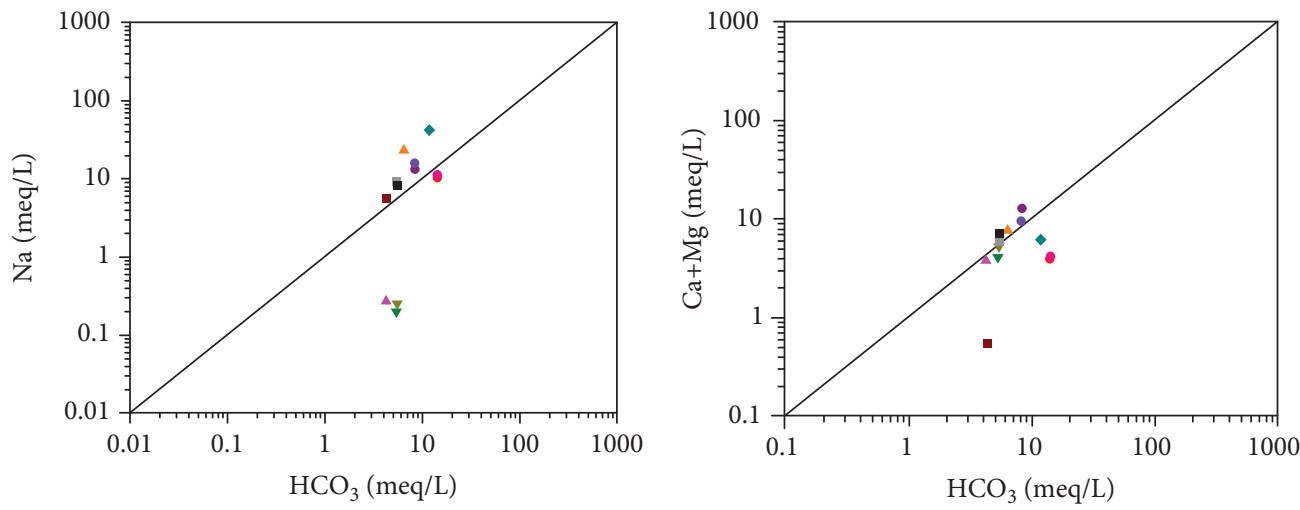

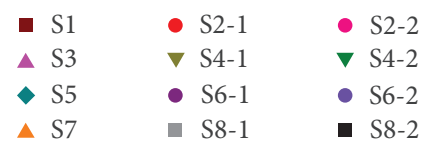

(a)
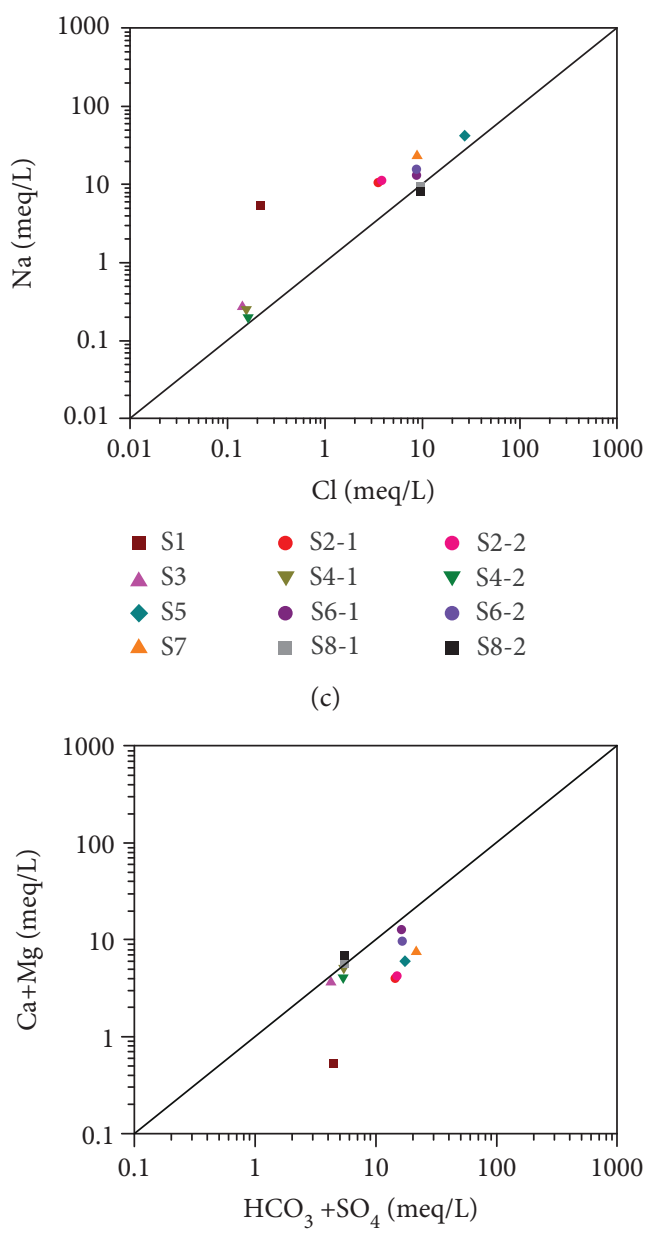

(e)
- $\mathrm{S} 1$

- S2-1

V S4-1

- S6-1

- S8-1

(c)

- $\mathrm{S} 1$

- S3

- S2-1

$\nabla$ S4-1

- S6-1

- S8-1

- $\mathrm{S} 2-2$

จ S4-2

- $56-2$

- S8-2

- S5

- S7
- $\mathrm{S} 2-2$

$\nabla$ S4-2

- S6-2

- $\mathrm{S} 8-2$
- $\mathrm{S} 1$

- S3

- S5

- 57

- S2-1

จ S4-1

- S6-1

- S8-1

(b)

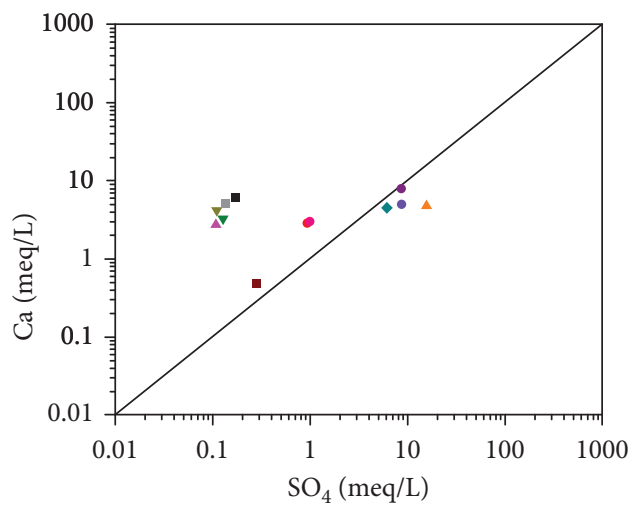

- $\mathrm{S} 1 \quad$ - $\mathrm{S} 2-1 \quad \bullet \mathrm{S} 2-2$

$\Delta \mathrm{S} 3 \quad \nabla \mathrm{S} 4-1 \quad \nabla \mathrm{S} 4-2$

$\rightarrow \mathrm{S} 5 \quad \bullet \mathrm{S} 6-1 \quad \bullet \mathrm{S} 6-2$

$\triangle \mathrm{S} 7 \quad-\mathrm{S} 8-1 \quad$ - $88-2$

(d)

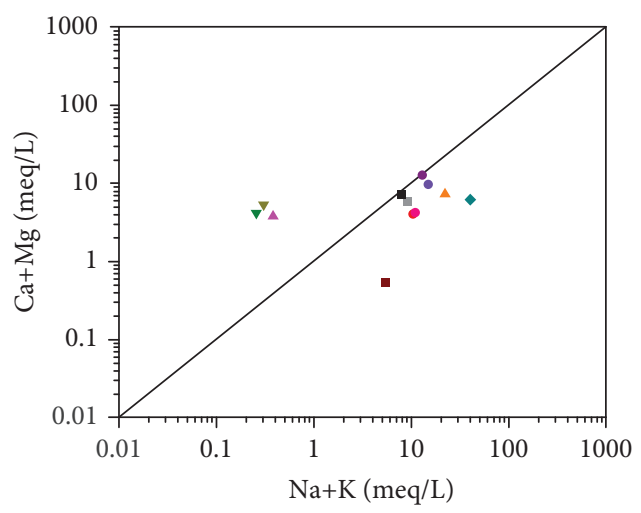

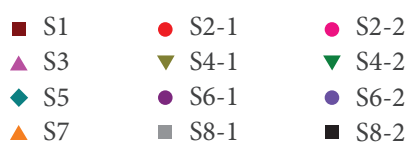

(f)

Figure 6: Relationship between major constituents in the springs in the Simao Basin: (a) $\mathrm{Na}$ vs. $\mathrm{HCO}_{3}$; (b) $\mathrm{Ca}+\mathrm{Mg}$ vs. $\mathrm{HCO}$; (c) $\mathrm{Na}$ vs. $\mathrm{Cl}$; (d) $\mathrm{Ca}$ vs. $\mathrm{SO}_{4}$; (e) $\mathrm{Ca}+\mathrm{Mg}$ vs. $\mathrm{HCO}_{3}+\mathrm{SO}_{4}$; (f) $\mathrm{Ca}+\mathrm{Mg}$ vs. $\mathrm{Na}+\mathrm{K}$. 


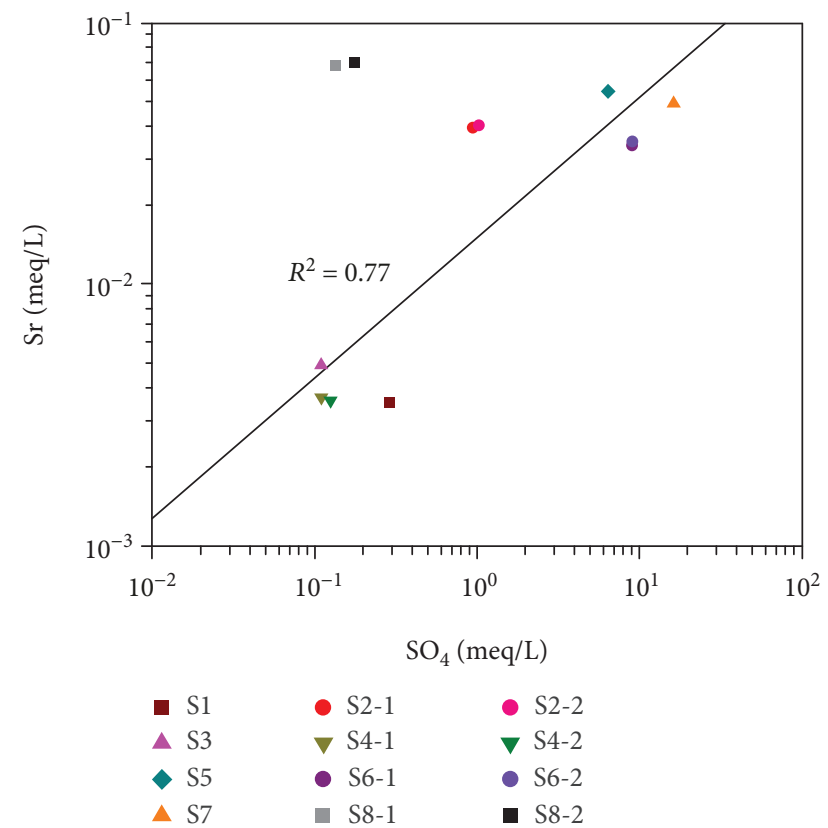

FIGURE 7: Relationship of $\mathrm{Sr}$ and $\mathrm{SO}_{4}$ in the spring samples in the Simao Basin.

metamorphic rocks and red beds. Concentrations of $\mathrm{F}$ and $\mathrm{H}_{2} \mathrm{SiO}_{3}$ are usually high in thermal groundwater; consequently, they are generally used as indicators of thermal groundwater. F widely occurs in rock-forming minerals such as amphibole, biotite, feldspar, and muscovite. F content in the metamorphic rocks is usually higher than $\mathrm{Cl}$ content, while that in the carbonate rocks is much lower than $\mathrm{Cl}$ content. There is less $\mathrm{F}$ in the red sandstones and mudstones, which is often undetectable. The $\mathrm{F}$ content in sample $\mathrm{S} 1$ is the highest $(16.7 \mathrm{mg} / \mathrm{L})$, followed by samples S3, S4-1, and S4-2 (0.39-0.65 mg/L). Except for S2-1 and S2-2 containing a small amount of F (0.29-0.32 mg/L), $\mathrm{F}$ was not detected in other springs in the red beds. This also validates the above inference that spring waters S2-1 and S2-2 are mixed with the terrestrial water in the eastern Simao Basin. The concentration of $\mathrm{SiO}_{2}$ increases with the temperature as shown in Figure 8. Thus, $\mathrm{SiO}_{2}$ can be used as a reliable geothermometer for estimating the deep reservoir temperature. $\mathrm{H}_{2} \mathrm{SiO}_{3}$ with concentration in the water samples ranging from 17.9 to $81 \mathrm{mg} / \mathrm{L}$ is mainly derived from incongruent dissolution of the surrounding $\mathrm{SiO}_{2}$-bearing rocks during groundwater circulation.

5.2.5. Saturation Index. The saturation index (SI) is a common indicator in hydrogeochemistry that can determine the reaction states of mineral phases in groundwater. The saturation state of hot springs in the Simao Basin with respect to selected mineral phases was computed at the $\mathrm{pH}$ and water temperature measured in the field, using the PHREEQC code [30]. Except for that of fluorite in sample S1, SI values of almost all selected minerals are less than 0 , indicating a dissolution stage with varying potentials for dissolution. Four trends of the mineral saturation indices are shown in Figure 9(a). (1) There is no obvious difference in the SI values

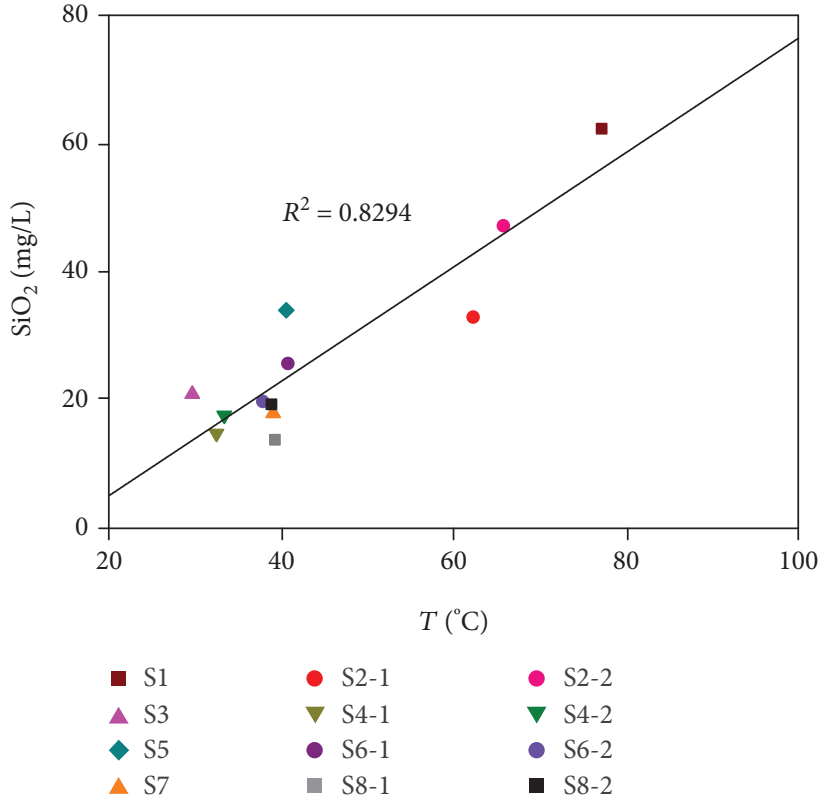

FIgURE 8: Relationship between $\mathrm{SiO}_{2}$ and temperature in the spring samples in the Simao Basin.

of carbonate minerals (calcite, aragonite, and dolomite) of all spring waters, which are closer to saturation than other minerals, showing that all springs undergo carbonate dissolution processes. (2) The SI values of sulfate minerals (gypsum, anhydrite, and celestite) of spring waters in the red beds are significantly higher than those of other types of spring waters, showing the tendency for the dissolution of those minerals. The lower SI values of springs in the metamorphic and carbonate rocks indicate a limited dissolution of those sulfate minerals. (3) The significant negative SI values of halite and sylvite of spring samples S1, S3, S4-1, and S4-2 in the metamorphic and carbonate rocks indicate that halite and sylvite dissolution is probably much limited in the reservoirs. However, the halite SI values of spring samples S8-1 and S8-2 in the carbonate rocks are consistent with those of springs in the red beds, indicating dissolution tendency for halite. (4) The SI value of fluorite was calculated only for the water samples in which F was detected. The SI value of the water sample $\mathrm{S} 1$ is greater than 0 , showing a saturated state and indicating the contribution of fluorite dissolution to the content of $\mathrm{F}$ in the spring water in metamorphic rocks. The evolution of SI with TDS is shown in Figure 9(b). The SI values of calcite and dolomite are independent of TDS, while those of halite and gypsum tend to increase with TDS, suggesting that the dissolution of halite and gypsum could be the main process for the increase of salinity.

5.3. Geothermometers. Solute geothermometers are widely used to estimate geothermal reservoir temperature under different conditions. Several geothermometers (Quartz, Chalcedony, Na-K, Na-K-Ca, and $\mathrm{Na}-\mathrm{Li}$ ) are used based on the chemical analyses of hot waters collected in this study, with the results summarized in Table 3. The calculation results show little consistency among the different methods. 


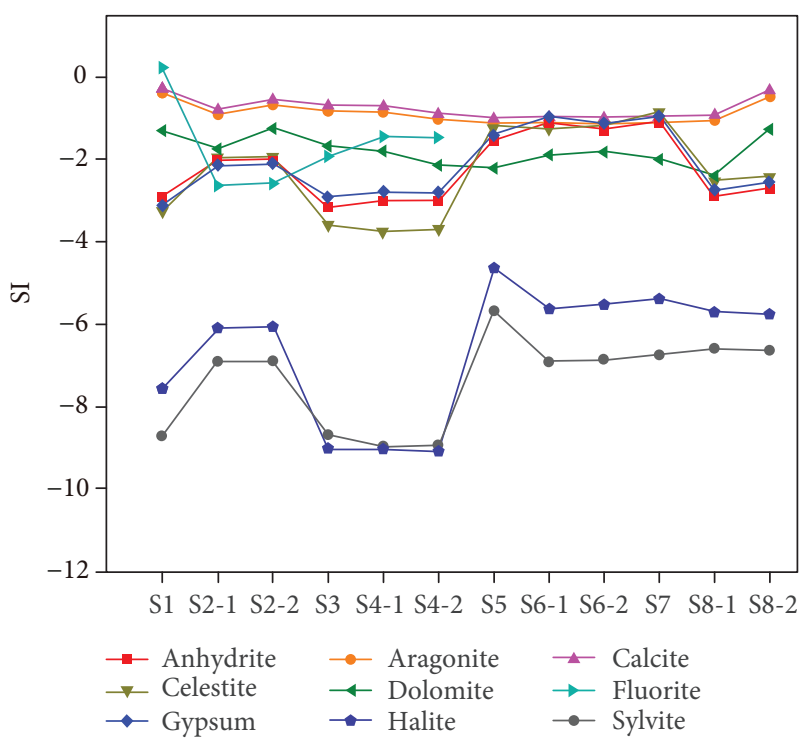

(a)

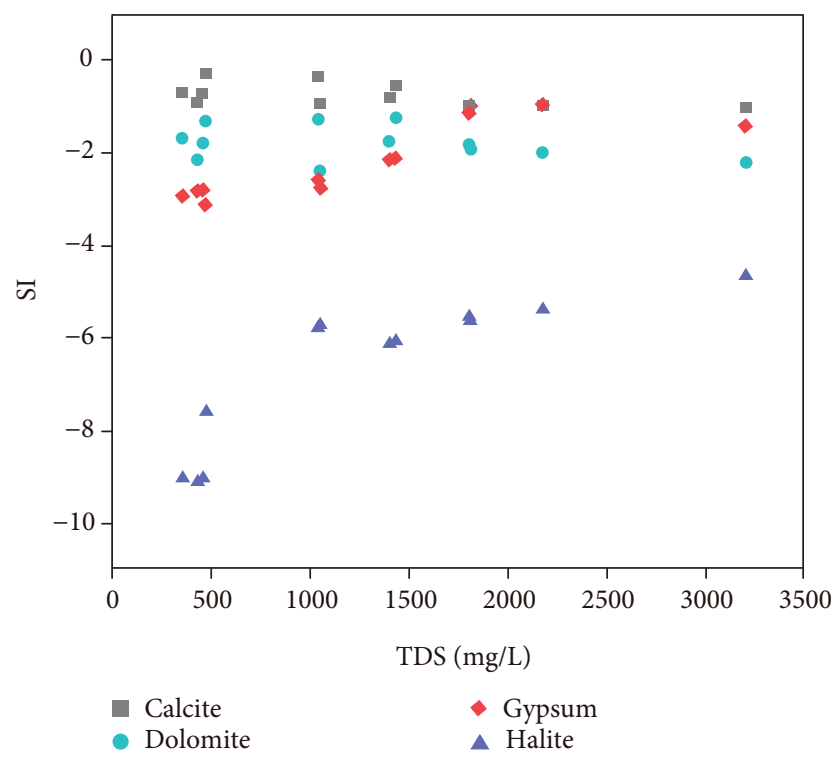

(b)

FIGURE 9: (a) Saturation indices of the main minerals for the springs in the Simao Basin; (b) evolution of saturation indices of calcite, dolomite, gypsum, and halite with TDS.

The cation geothermometer is established based on the concentration ratios of the dissolved components indicating the temperature at which the thermal groundwater reaches equilibrium at depth with the surrounding rock [8]. Mixing of hot groundwater with cold water and lack of a full chemical equilibrium in the deep geothermal reservoir may lead to uncertain results calculated by the cation geothermometers. In this study, three cation geothermometers, namely, Na-K geothermometer, Na-K-Ca geothermometer, and $\mathrm{Na}-\mathrm{Li}$ geothermometer, are used to calculate the reservoir temperatures. The $\mathrm{Na}-\mathrm{K}$ geothermometer is adapted for reservoir temperatures in the range of 180 to $350^{\circ} \mathrm{C}$ and the estimated reservoir temperatures in the study area range from below 150 to $500^{\circ} \mathrm{C}$. The Na-K-Ca geothermometer is suitable for reservoir temperatures in the range of 0 to $340^{\circ} \mathrm{C}$, and the estimated reservoir temperatures ranging from 9 to $166^{\circ} \mathrm{C}$ are much lower than those calculated with the $\mathrm{Na}-\mathrm{K}$ geothermometer, possibly due to the mixing with the shallow cold water. It can be clearly seen that the calculation results of samples S3, S4-1, and S4-2 with the Na-K geothermometer and the $\mathrm{Na}-\mathrm{K}-\mathrm{Ca}$ geothermometer are extremely inaccurate, probably because these two geothermometers are based on the ion exchange between feldspars while $\mathrm{Na}, \mathrm{K}$, and $\mathrm{Ca}$ in the spring water samples in the Simao Basin are derived from the incongruent dissolution of evaporites and carbonates, which are not controlled by the feldspar ion exchange. The reservoir temperatures estimated with the $\mathrm{Na}$-Li geothermometer range from 70 to $180^{\circ} \mathrm{C}$. However, the $\mathrm{Na}-\mathrm{Li}$ geothermometer appears to be sensitive to the TDS of the water at depth and is affected locally by contributions of $\mathrm{Na}-\mathrm{Cl}$ and the rock type [7]. Therefore, the $\mathrm{Na}-\mathrm{Li}$ geothermometer is not reliable for brackish water. The Na$\mathrm{K}-\mathrm{Mg}$ triangle diagram [31] is used to distinguish groundwaters which attained equilibrium with the host lithology (Figure 10) [7]. All the water sample points in the Simao Basin fall in the immature water area, indicating that the cation geothermometers are not suitable for calculating the reservoir temperatures in this study and also suggesting the effect of mixing [31].

The $\mathrm{SiO}_{2}$ geothermometer is established based on the theory of dissolution-precipitation equilibrium of siliconbearing minerals in thermal groundwater [32]. In most natural waters, dissolved silica is not easily influenced by common ion effects, the formation of complexes, and the loss of volatile components [8]. Moreover, silica minerals are widespread and abundant, and the precipitation rate of silica is very slow when temperature is low. Thus, the $\mathrm{SiO}_{2}$ geothermometer has been regarded as the earliest and the most common geochemical geothermometer. Under the nonequilibrium conditions, silica geothermometers may provide more dependable results than cation geothermometers [33]. As mentioned earlier, the hot spring waters studied are mixtures of thermal groundwater with shallow cold waters, which lead to large dilution of the silica concentrations. Therefore, the temperatures calculated with $\mathrm{SiO}_{2}$ geothermometers are considered as the minimum reservoir temperatures. Two $\mathrm{SiO}_{2}$ geothermometers including a quartz geothermometer and a chalcedony geothermometer are used to estimate the reservoir temperatures in this study. The reservoir temperatures calculated with the quartz geothermometer vary between $51^{\circ} \mathrm{C}$ and $127^{\circ} \mathrm{C}$, and those with the chalcedony geothermometers, between $19^{\circ} \mathrm{C}$ and $100^{\circ} \mathrm{C}$. At temperatures less than $180^{\circ} \mathrm{C}$, the solubility of silica is usually controlled by chalcedony rather than quartz [11]. However, as can be seen, the reservoir temperatures calculated with the chalcedony geothermometer are lower than those with the quartz geothermometer. It is obviously inaccurate that the calculated temperatures are less than or close to the temperatures of the springs. Therefore, the results $\left(51^{\circ} \mathrm{C}-127^{\circ} \mathrm{C}\right)$ estimated with the quartz geothermometer is more reliable.

Fluid-mineral equilibrium calculations were also used to estimate the reservoir temperatures. If a set of minerals in a hydrothermal fluid is almost simultaneously equilibrated in 
TABLE 3: Estimated reservoir temperatures of the hot springs in the Simao Basin.

\begin{tabular}{|c|c|c|c|c|c|c|c|c|}
\hline \multirow{2}{*}{ Sample } & \multirow{2}{*}{ Water temperature $\left({ }^{\circ} \mathrm{C}\right)$} & \multicolumn{6}{|c|}{ Reservoir temperature $\left({ }^{\circ} \mathrm{C}\right)$} & \multirow[b]{2}{*}{ Multimineral equilibrium } \\
\hline & & Quartz & Quartz (max. steam loss) & Chalcedony & $\mathrm{Na}-\mathrm{K}$ & $\mathrm{Na}-\mathrm{K}-\mathrm{Ca}$ & $\mathrm{Na}-\mathrm{Li}$ & \\
\hline S1 & 77.2 & 127 & 124 & 99 & $<150$ & 96 & 177 & 133 \\
\hline S2-1 & 62.3 & 115 & 114 & 86 & 198 & 165 & 180 & 125 \\
\hline S2-2 & 65.8 & 119 & 117 & 91 & 194 & 164 & 178 & 138 \\
\hline S3 & 29.7 & 77 & 81 & 46 & 500 & 31 & 134 & 113 \\
\hline S4-1 & 32.5 & 66 & 71 & 34 & 389 & 9 & 130 & 125 \\
\hline S4-2 & 33.4 & 66 & 71 & 34 & 426 & 11 & 137 & 128 \\
\hline S5 & 40.6 & 104 & 104 & 74 & $<150$ & 151 & 104 & 144 \\
\hline S6-1 & 40.8 & 81 & 84 & 50 & $<150$ & 55 & 74 & 122 \\
\hline S6-2 & 37.9 & 83 & 86 & 51 & $<150$ & 68 & 71 & 116 \\
\hline S7 & 39.1 & 74 & 78 & 43 & $<150$ & 83 & 102 & 114 \\
\hline S8-1 & 39.3 & 52 & 59 & 20 & 168 & 76 & 131 & 91 \\
\hline S8-2 & 38.9 & 55 & 61 & 23 & 173 & 69 & 137 & 97 \\
\hline
\end{tabular}

Geothermometer of quartz is $T=1309 /\left(5.19-\operatorname{lgSiO}_{2}\right)-273.15$ [8]; quartz (max. steam loss), $T=1522 /\left(5.75-\operatorname{lgSiO}_{2}\right)-273.15$ [8]; chalcedony, $T=1032 /(4.69$ $\left.\operatorname{lgSiO}_{2}\right)-273.15$ [8]; Na-K, T=933/[0.933 $\left.+\lg (\mathrm{Na} / \mathrm{K})\right]-273.15[41] ; \mathrm{Na}-\mathrm{K}-\mathrm{Ca}, T=1647 /\left\{\lg (\mathrm{Na} / \mathrm{K})+\beta\left[\lg \left(\mathrm{Ca}{ }^{1 / 2} / \mathrm{Na}\right)+2.06\right]+2.47\right\}-273.15[42] ; \mathrm{Na}-\mathrm{Li}$, $T=1000( \pm 47) /[0.27+\lg (\mathrm{Na} / \mathrm{Li})]-273.15$ when $\mathrm{Cl}<0.3 \mathrm{~g} / \mathrm{L} ; \mathrm{Na}-\mathrm{Li}, T=1195( \pm 75) /[\lg (\mathrm{Na} / \mathrm{Li})-0.06]-273.15$ when $\mathrm{Cl}>0.3 \mathrm{~g} / \mathrm{L}[43]$.

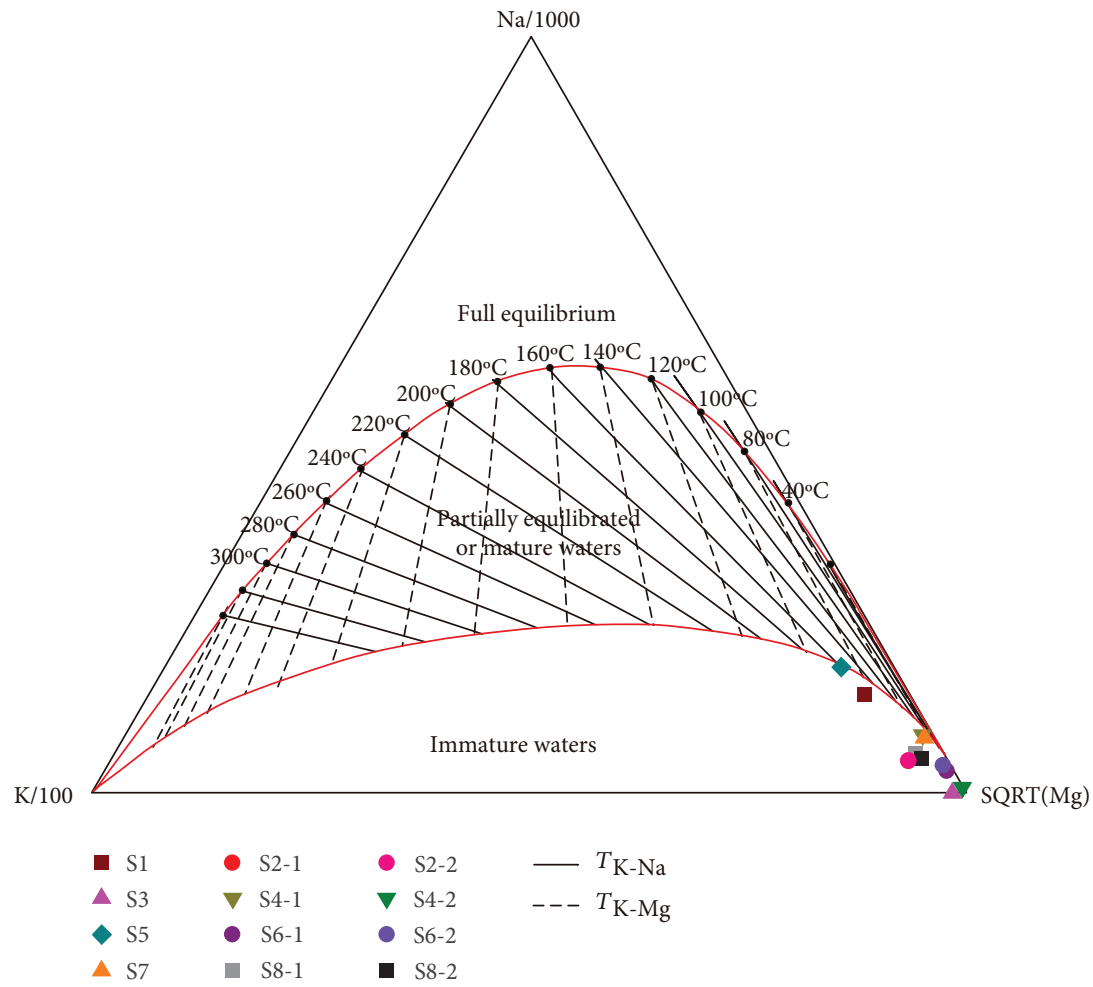

Figure 10: Na-K-Mg triangle diagram showing the hot spring water samples in the Simao Basin ( $T_{\mathrm{K}-\mathrm{Na}}$ is a set of isotherm according to the $\mathrm{K}-\mathrm{Na}$ geothermometer; $T_{\mathrm{K}-\mathrm{Mg}}$ is a set of isotherm according to the $\mathrm{K}-\mathrm{Mg}$ geothermometer).

a small temperature range, the equilibrium temperature is the geothermal reservoir temperature [34]. However, this method is not suitable for the low-moderate temperature geothermal system in the Simao Basin. The SI for the selected minerals at different temperatures were calculated using the computer program WATCH97 [35], and the fluid-mineral equilibrium diagram is drawn taking sample $\mathrm{S} 1$ as an exam- ple. As can be seen in Figure 11(a), only a few minerals (quartz, chalcedony, and talc) reach partial equilibria. The content of aluminum in the geothermal system is low and difficult to determine, resulting in lack of $\mathrm{Al}$ determination in many chemical analyses, thereby the inexistence of aluminum-bearing silicate minerals in the fluid-mineral equilibrium diagrams. It is considered that there are always 


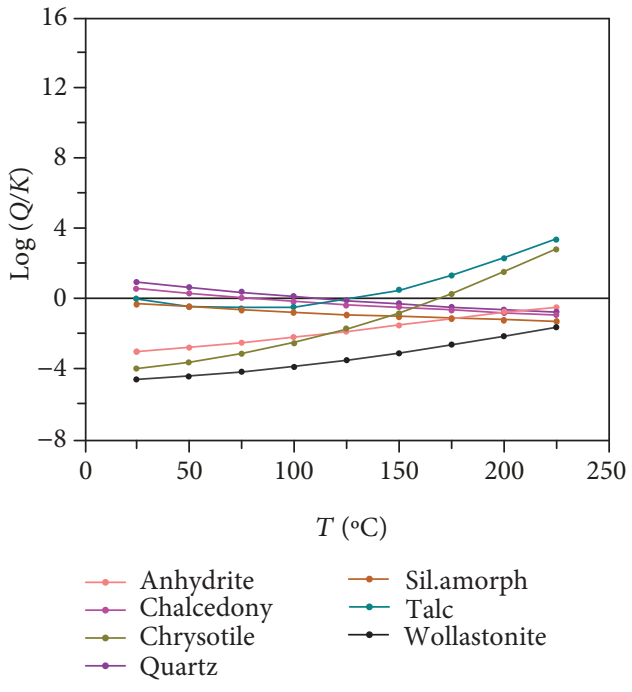

(a)

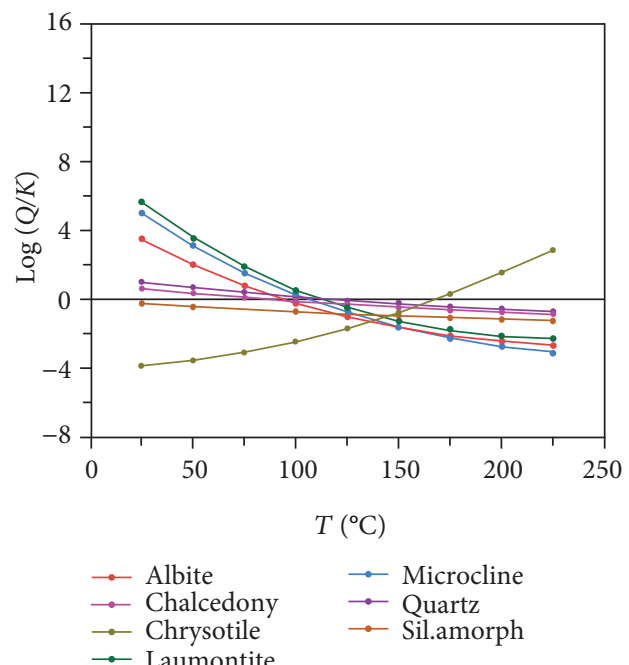

(b)

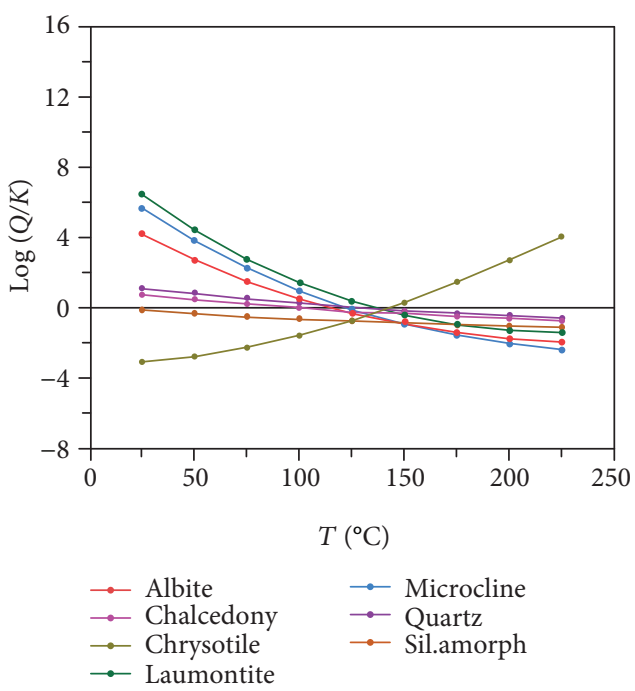

(c)

FIgURE 11: $\log (Q / K)$ vs. $T$ diagram of the hot spring water sample $\mathrm{S} 1$ in the Simao Basin. more than two aluminum-bearing silicate minerals reaching equilibrium in the common geothermal system [36], so we use the fixed-Al method that forces the water to be at equilibrium with selected Al-bearing minerals [6]. In Figure 11(b), it is assumed that the concentration of aluminum is $0.1 \mathrm{mg} / \mathrm{L}$, with the concentration of the rest of the components remaining unchanged. It can be seen that alteration minerals such as albite, chalcedony, laumontite, microcline, and quartz in a low-moderate temperature geothermal system basically intersect at $130^{\circ} \mathrm{C}$ which is slightly higher than the reservoir temperature calculated with the quartz geothermometer, showing a good convergence. Nevertheless, the value of the intersection is slightly less than 0 . In Figure 11(c), considering the influence of the mixing of thermal groundwater with cold waters, it is assumed that the concentration of aluminum is $0.1 \mathrm{mg} / \mathrm{L}$, with the concentration of the rest of the components multiplied by 1.6. The above minerals converge at $130^{\circ} \mathrm{C}$, with the SI value of intersection point of 0 , indicating that water sample $\mathrm{S} 1$ reaches equilibrium at $130^{\circ} \mathrm{C}$.

Figure 12 is a fixed-Al diagram considering the mixing effect of 12 water samples in the Simao Basin, assuming that the concentration of aluminum is $0.1 \mathrm{mg} / \mathrm{L}$ and the concentration of the rest of the components are multiplied by appropriate coefficients $(\mathrm{S} 1 \times 1.6, \mathrm{~S} 2-1 \times 2.2, \mathrm{~S} 2-2 \times 2.3$, $\mathrm{S} 3 \times 2.6, \mathrm{~S} 4-1 \times 2.6, \mathrm{~S} 4-2 \times 2.6, \mathrm{~S} 5 \times 2.6, \mathrm{~S} 6-1 \times 2.6, \mathrm{~S} 6-2 \times$ $2.6, \mathrm{~S} 7 \times 2.6, \mathrm{~S} 8-1 \times 2.6$, and S8-2 $\times 2.6$ ). For water samples $\mathrm{S} 1$ to $\mathrm{S} 8-2$, the various minerals converge at $130^{\circ} \mathrm{C}, 125^{\circ} \mathrm{C}$, $127^{\circ} \mathrm{C}, 113^{\circ} \mathrm{C}, 125^{\circ} \mathrm{C}, 128^{\circ} \mathrm{C}, 132^{\circ} \mathrm{C}, 122^{\circ} \mathrm{C}, 116^{\circ} \mathrm{C}, 114^{\circ} \mathrm{C}$, $91^{\circ} \mathrm{C}$, and $97^{\circ} \mathrm{C}$, respectively, which are consistent with the reservoir temperatures obtained in Figure 10, with values ranging from $80^{\circ} \mathrm{C}$ to $160^{\circ} \mathrm{C}$.

The above analyses indicate that the heat of the spring waters in the Simao Basin is derived from the deep heat flow. If the temperature of the geothermal water is increased due to heat flow, the circulation depth can be roughly calculated with the following equation [37]:

$$
Z=G\left(T-T_{0}\right)+Z_{0},
$$

where $Z$ is the circulation depth of geothermal water $(\mathrm{m}), G$ is the geothermal level (reciprocal of the geothermal gradient), $T$ is the reservoir temperature $\left({ }^{\circ} \mathrm{C}\right), T_{0}$ is the annual average temperature in the study area $\left({ }^{\circ} \mathrm{C}\right)$, and $Z_{0}$ is the thickness of the constant temperature zone $(\mathrm{m}) . G$ in the Simao Basin is $34.5 \mathrm{~m} /{ }^{\circ} \mathrm{C}$ [38], $T$ is $20^{\circ} \mathrm{C}$, and $Z_{0}$ is $25 \mathrm{~m}$. The calculated circulation depths are shown in Table 4 . It can be seen that the circulation depths of the spring waters in the Simao Basin range from 2474 to $3889 \mathrm{~m}$, suggesting processes of deep circulation. Considering the geological conditions, the circulation depth of the springs in the Simao Basin is greatly affected by the development degree of fractures and faults that control the emergence of springs.

5.4. Mixing Models. It is mentioned previously that the ascending thermal groundwater may cool by mixing with shallow cold waters, leading to varying temperatures of the springs. The proportion of the thermal groundwater and cold waters in mixing can be estimated by mixing models including the silica-enthalpy equation method and silica-enthalpy 

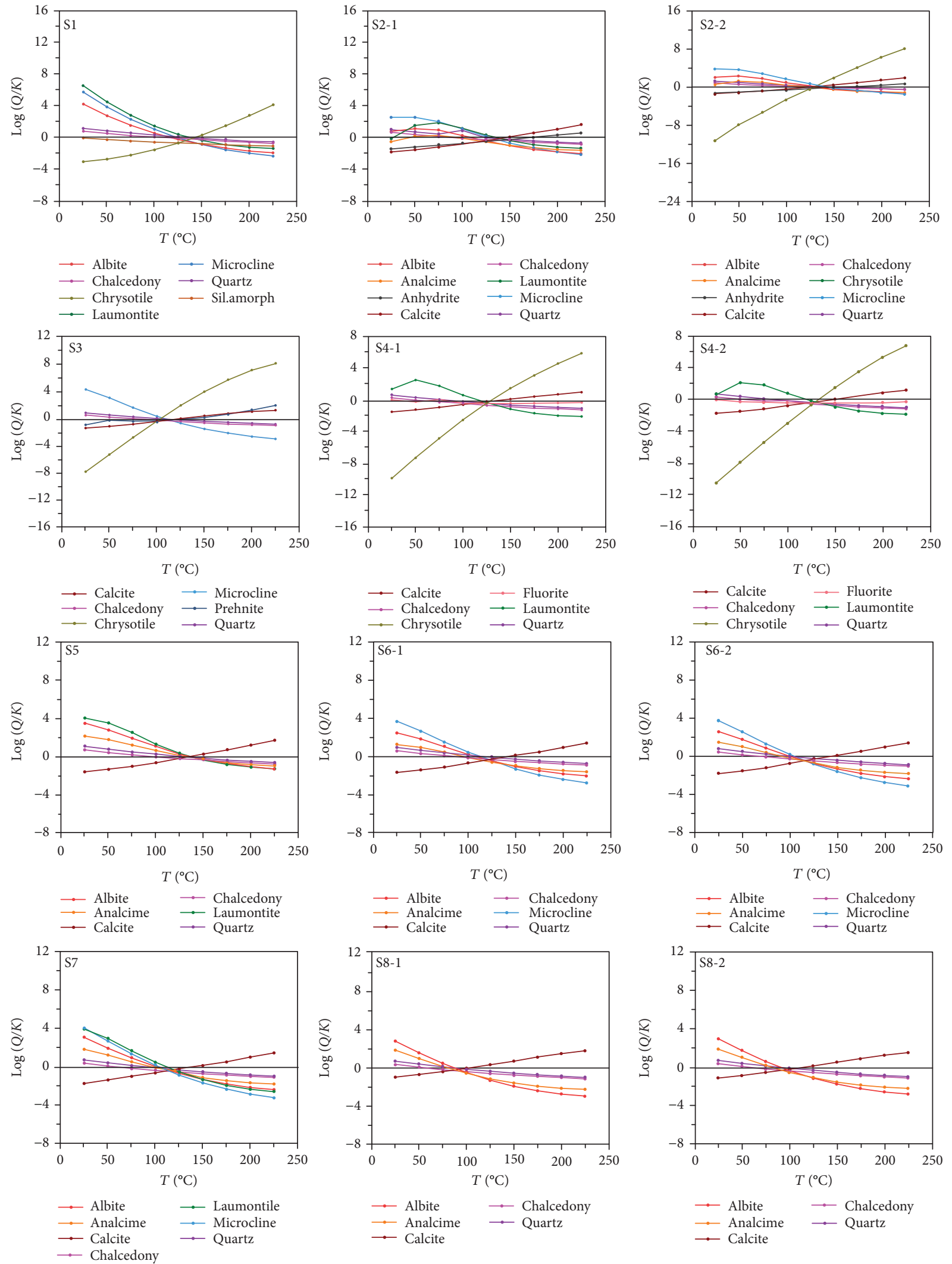

FIgURE 12: Fixed-Al diagram showing the hot spring water samples in the Simao Basin. 
TABLE 4: Estimated circulation depths of the hot springs in the Simao Basin.

\begin{tabular}{lccc}
\hline Sample & $\begin{array}{c}\text { Water temperature } \\
\left({ }^{\circ} \mathrm{C}\right)\end{array}$ & $\begin{array}{c}\text { Reservoir temperature } \\
\left({ }^{\circ} \mathrm{C}\right)\end{array}$ & $\begin{array}{c}\text { Circulation } \\
\text { depth }(\mathrm{m})\end{array}$ \\
\hline S1 & 77.2 & 130 & 3820 \\
S2-1 & 62.3 & 125 & 3647.5 \\
S2-2 & 65.8 & 127 & 3716.5 \\
S3 & 29.7 & 113 & 3233.5 \\
S4-1 & 32.5 & 125 & 3647.5 \\
S4-2 & 33.4 & 128 & 3751 \\
S5 & 40.6 & 132 & 3889 \\
S6-1 & 40.8 & 122 & 3544 \\
S6-2 & 37.9 & 116 & 3337 \\
S7 & 39.1 & 114 & 3268 \\
S8-1 & 39.3 & 91 & 2474.5 \\
S8-2 & 38.9 & 97 & 2681.5 \\
\hline
\end{tabular}

graphical method, based on the chemical contents of cold and mixed hot water samples. In this case, the mixing models are likely to indicate the original temperature of the thermal groundwater component, which can be used as a reference for the reservoir temperatures [8].

Two equations were proposed to solve the proportion of the cold water in mixing based on the dissolved silica contents and enthalpy values of cold and mixed hot waters [39]:

$$
\begin{gathered}
H_{\mathrm{c}} X_{1}+H_{\mathrm{h}}\left(1-X_{1}\right)=H_{\mathrm{s}}, \\
\mathrm{SiO}_{2 \mathrm{c}} X_{2}+\operatorname{SiO}_{2 \mathrm{~h}}\left(1-X_{2}\right)=\mathrm{SiO}_{2 \mathrm{~s}},
\end{gathered}
$$

where $X$ is the proportion of the cold water in mixing, $H_{c}$ is the enthalpy of cold water, $H_{\mathrm{h}}$ is the enthalpy of deep hot water, $H_{s}$ is the enthalpy of mixed hot water, $\mathrm{SiO}_{2 c}$ is the silica content of cold water, $\mathrm{SiO}_{2 \mathrm{~h}}$ is the silica content of deep hot water, and $\mathrm{SiO}_{2 s}$ is the silica content of mixed hot water. Solve equations (5) and (6) for $X$ at different temperatures and different silica contents of deep hot waters, respectively, and plot the relationship between $X$ and temperature to obtain two curves. The intersection point gives the estimated initial temperature of thermal groundwater component and the proportion of cold water (Figure 13).

The silica-enthalpy diagram is used to estimate the proportion of cold water, the steam loss, and the initial temperature of thermal groundwater component [40]. As shown in Figure 14, the two curves in the dissolved silica-enthalpy diagrams are the maximum steam loss curve and the quartz solubility curve, respectively. If the water samples probably have cooled adiabatically (by boiling) before sampling, the maximum steam loss curve is used. If the water samples are likely to cool by conduction, the quartz solubility curve is employed [8]. As the water samples in the study area have flowed for a long distance and ascend slowly to the land surface, conductive cooling is likely to occur. Therefore, the quartz solubility curve is used in this paper. As illustrated in Figure 14, the silica contents and enthalpy values of the cold water (rain water) and the mixed hot spring water are plotted as two points, A and B. Drawing a straight line from points A to B and intersecting the quartz solubility curve at point $C$ give the original silica content and enthalpy of the deep hot water [8]. The ratio of the length of line $\mathrm{BC}$ to line $\mathrm{AC}$ is the proportion of the cold water in mixing.

The reservoir temperature calculated with the two methods considering the mixing effect and the cold water mixing proportion of hot springs in the Simao Basin are shown in Table 5. For waters in nonequilibrium, there are large errors of the reservoir temperatures estimated with the mixing models, with the temperature ranging from $76^{\circ} \mathrm{C}$ to $194^{\circ} \mathrm{C}$, which are much higher than temperatures calculated with the fixed-Al diagram $\left(91^{\circ} \mathrm{C}-132^{\circ} \mathrm{C}\right)$, except those of samples S2-1 and S8-1. The ratios of cold water in mixing range from $58 \%$ to $94 \%$. The water sample that mixed with the maximum cold waters is S4-2, with a ratio of $93.85 \%$. Besides, the gap of sample S4-2 between the reservoir temperature estimated with the fixed-Al diagram and the temperature estimated with the $\mathrm{SiO}_{2}$ geothermometer is the largest, indicating that the mixing of hot and cold waters has a greater impact on the calculation of reservoir temperatures. The springs S4-1 and S4-2 occur near a small river; thus, it is inferred that the excessively high proportion of cold water results from the mixing of spring water and large amount of river water. There is no intersection point $\mathrm{C}$ at the silica-enthalpy diagram of sample S3, indicating that the heat was lost before the mixing of hot with cold waters. The outlet of spring S3 is a pumping well located in the center of a pond, which cannot be sampled. It was taken from the nearby faucet; consequently, the temperature of the spring S3 was reduced. The graphical result of sample S3 is consistent with the actual situation.

5.5. Formation of the Hot Springs. The Simao Basin is located in the Yunnan-Tibet geothermal belt, with strong tectonic activities. The faults were well developed, which provide good conditions for the occurrence of the hot springs [16]. The deep faults are helpful in providing deep heat for the spring waters. The regional faults are considered as waterflowing channels which provide the condition for the transport of groundwater. The small faults and fissures developed by the main faults are favorable for the emergence of the spring waters.

There are large differences in the discharge among the three types of springs, which are mainly dependent on the stratigraphic lithology and faults. In the study area, the karst and fissures are well developed in the carbonate rocks, resulting in sufficient yield to wells; thus, the springs in the carbonate rocks are of relatively large discharge. The metamorphic strata are commonly of low permeability, while strong tectonic activities occurred in the Ailaoshan area, forming some faults characterized by large depth and wide width of well-developed fractures [17]. As a result, springs emerge in the Ailaoshan metamorphic rocks with higher temperatures and moderate discharge. The red sandstone and mudstone are also of low porosity and permeability. However, the Middle and Lower Jurassic, Upper Cretaceous, and Paleogene strata are salt-bearing formations in the Simao Basin, generally containing soluble minerals such as 

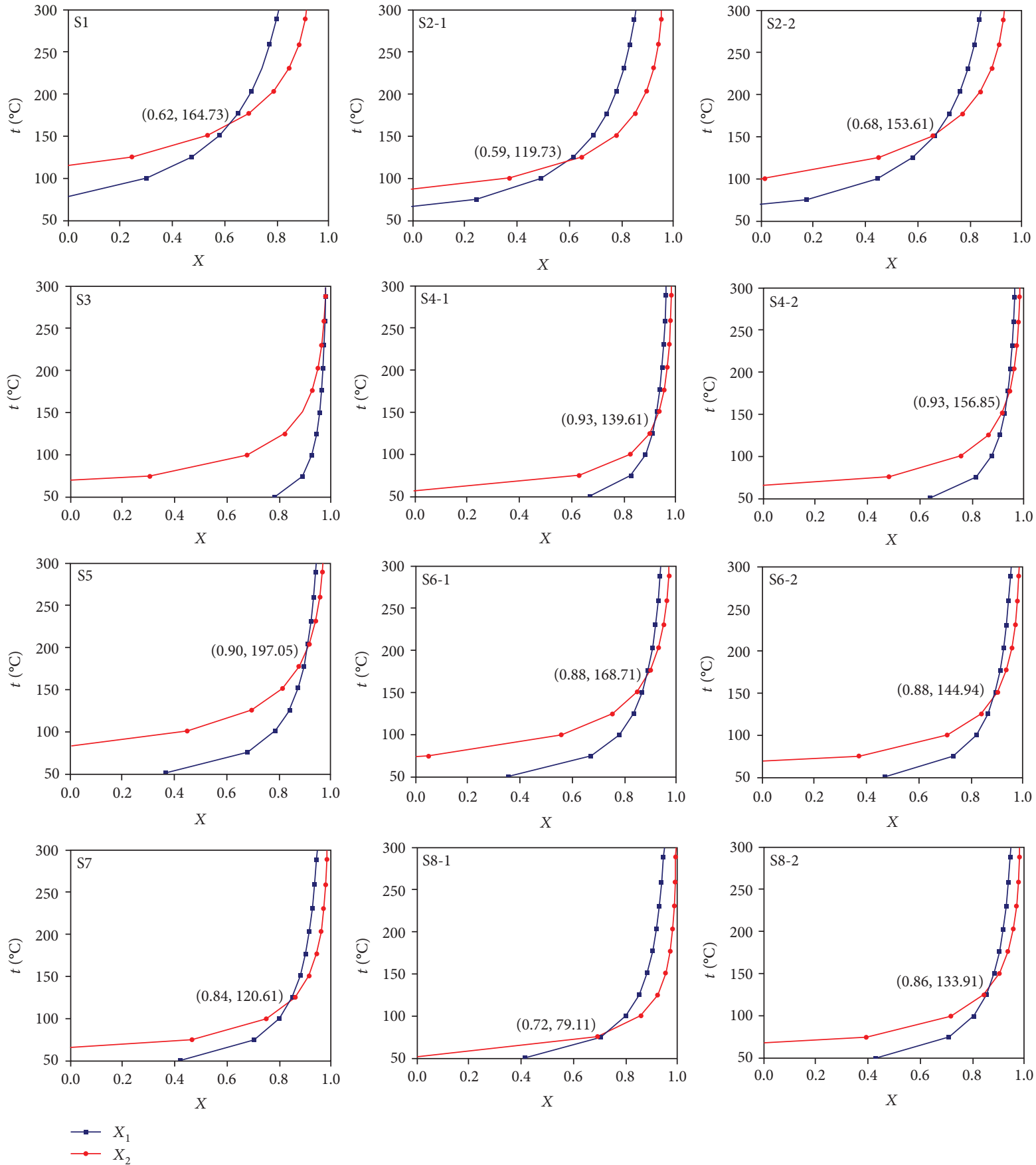

FIgURE 13: Diagram of temperature relative to proportion of cold water in the hot spring water samples in the Simao Basin $\left(X_{1}\right.$ is the proportion of the cold water in mixing calculated by the enthalpy; $X_{2}$ is the proportion of the cold water in mixing calculated by the content of $\mathrm{SiO}_{2}$ ).

halite, sylvite, and gypsum [17]. After a long-time dissolution, dissolved voids with good connectivity are generated as storage spaces of groundwater [15]. Therefore, springs with low discharge and higher TDS generally exist in the red beds in the study area.

Considering the topographical features and geological conditions of the Simao Basin (Figure 1) and taking the springs $\mathrm{S} 1$ in the metamorphic rocks, S2-1 in the red beds, S4-1 in the carbonate rocks, and S8-1 which exists in the carbonate rocks and is recharged in the nearby red-bed zone as examples, the conceptual models showing the formation of the three types of springs in the Simao Basin are proposed (Figure 15). The formation of the springs is roughly summarized as follows. Precipitation infiltrates into the underground in the mountain areas; groundwater converges and flows along the faults; when undergoing deep circulation, the groundwater is heated by heat flow from below and incongruent dissolution of the subsurface minerals occurs; and the thermal groundwater flows up to the surface in the form of hot springs. 

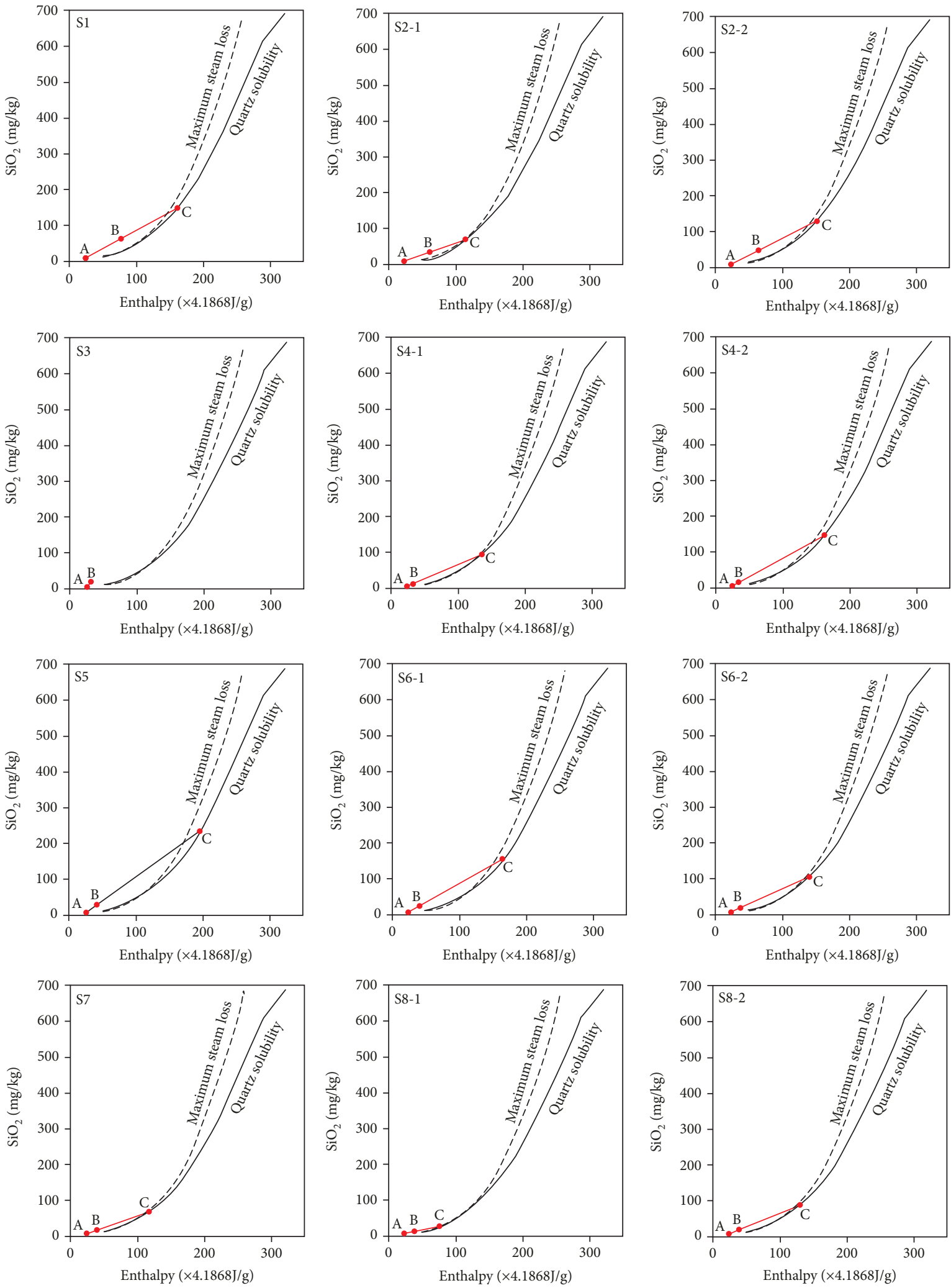

FIGURE 14: Dissolved silica-enthalpy diagram showing the hot spring water samples in the Simao Basin.

\section{Conclusions}

There are a series of deep NW-SE faults developed in the Simao Basin in Yunnan of China, which extend consistently and deeply, controlling the sedimentary and tectonic evolution of the basin. Three types of rocks exist in the basin. The thick Mesozoic and Cenozoic red beds were deposited in the depression areas in the basin. Due to the later 
TABLE 5: Reservoir temperatures considering the mixing effect and the steam loss and cold water mixing proportion of the hot springs in the Simao Basin.

\begin{tabular}{|c|c|c|c|c|c|}
\hline \multirow{2}{*}{ Sample } & \multirow{2}{*}{ Enthalpy $(\times 4.1868 \mathrm{~J} / \mathrm{g})$} & \multirow{2}{*}{$\mathrm{SiO}_{2}(\mathrm{mg} / \mathrm{L})$} & \multirow{2}{*}{ Reservoir temperature $\left({ }^{\circ} \mathrm{C}\right)$} & \multicolumn{2}{|c|}{ Cold water mixing proportion $(\%)$} \\
\hline & & & & Silica-enthalpy equation & Silica-enthalpy graph \\
\hline S1 & 160.99 & 147.98 & 160.99 & 61.35 & 61.64 \\
\hline S2-1 & 115.22 & 67.38 & 115.22 & 59.21 & 58.96 \\
\hline S2-2 & 152.51 & 128.51 & 152.51 & 67.72 & 68.07 \\
\hline S3 & - & - & - & - & - \\
\hline S4-1 & 134.94 & 97.23 & 134.94 & 92.63 & 93.38 \\
\hline S4-2 & 161.76 & 150.04 & 161.76 & 93.36 & 93.85 \\
\hline S5 & 194.05 & 236.39 & 194.05 & 90.39 & 89.50 \\
\hline S6-1 & 164.79 & 156.93 & 164.79 & 88.34 & 88.70 \\
\hline S6-2 & 140.56 & 107.06 & 140.56 & 88.46 & 88.99 \\
\hline S7 & 116.48 & 69.04 & 116.48 & 84.29 & 85.00 \\
\hline S8-1 & 76.49 & 27.88 & 76.49 & 71.81 & 73.41 \\
\hline S8-2 & 130.12 & 88.66 & 130.12 & 86.37 & 87.02 \\
\hline
\end{tabular}

Note: - indicates no data available.
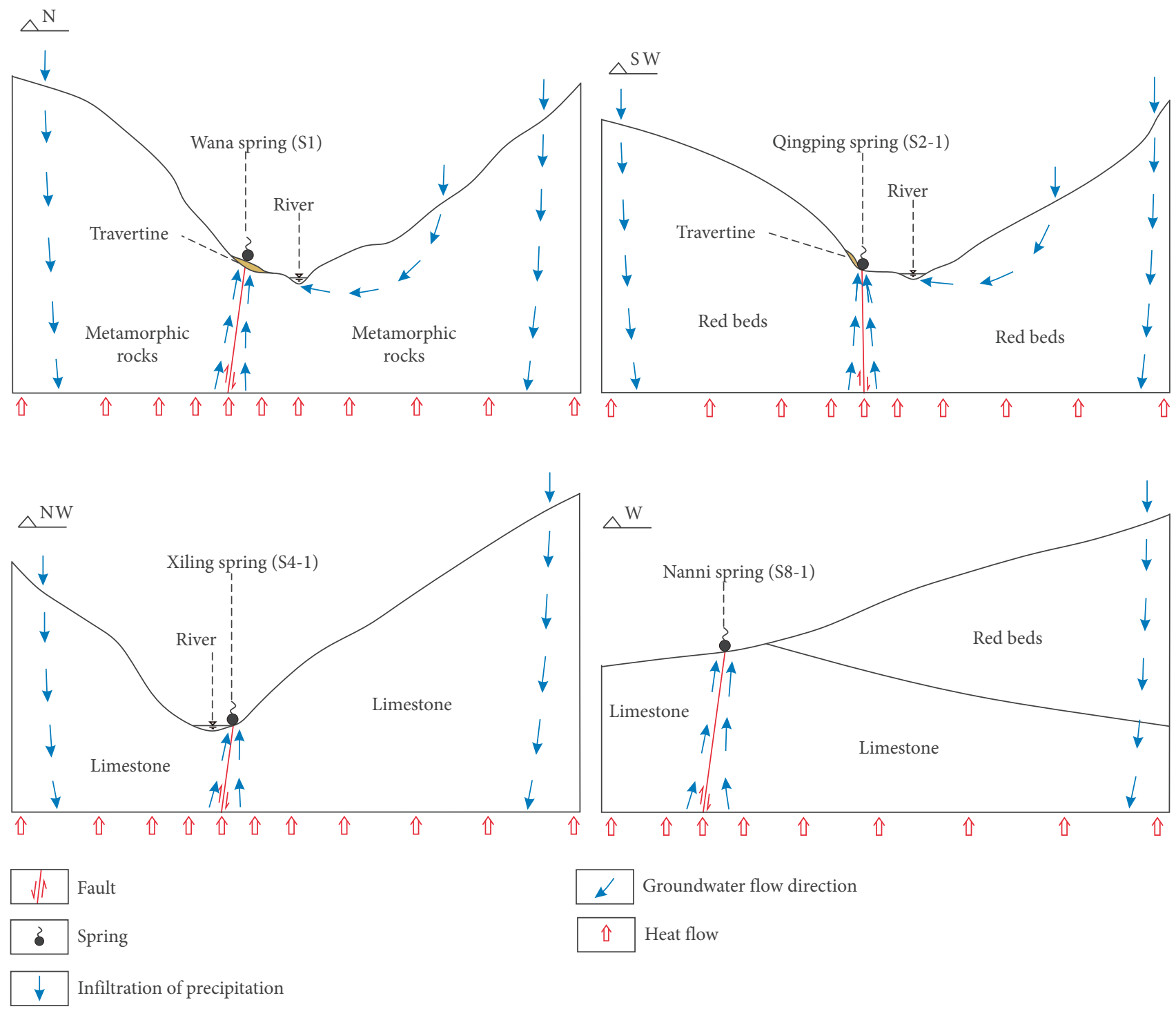

FIGURE 15: Schematic profiles showing the formation of the select hot springs in the Simao Basin. 
denudation, the Paleozoic carbonate rocks occur in the uplift areas in the basin. Controlled by deep faults, the Proterozoic metamorphic rocks occur at the edge of the basin.

The hot springs can be grouped according to their outcropping rocks: neutral springs with low TDS of $\mathrm{HCO}_{3}-\mathrm{Na}$ type emerge in the metamorphic rocks, weakly acidic springs with low TDS of $\mathrm{HCO}_{3}-\mathrm{Ca}(\mathrm{Mg})$ type exist in the carbonate rocks, and weakly acidic springs with higher TDS of $\mathrm{Cl}\left(\mathrm{SO}_{4}\right)-\mathrm{SO}_{4}(\mathrm{Cl})-\mathrm{HCO}_{3}-\mathrm{Na}(\mathrm{Ca})$ type occur in the red beds.

Data of $\delta^{2} \mathrm{H}$ and $\delta^{18} \mathrm{O}$ of the hot spring waters in the Simao Basin indicate that they are of meteoric origin. The chemical compositions are mainly influenced by the incongruent dissolution of subsurface minerals. High concentrations of $\mathrm{Na}$ and $\mathrm{HCO}_{3}$ in the hot spring waters in the metamorphic rocks are derived from the weathering of albite. $\mathrm{Ca}(\mathrm{Mg})$ and $\mathrm{HCO}_{3}$ in the hot spring waters in the carbonate area are derived from the dissolution of carbonate minerals. The solutes of the hot spring waters in the red beds as well as water samples S8-1 and S8-2 in the carbonate rocks originate from the incongruent dissolution of evaporites and carbonates. $\mathrm{Na}$ and $\mathrm{Cl}$ in the hot water come from the dissolution of halite, and $\mathrm{Ca}, \mathrm{Mg}, \mathrm{HCO}_{3}$, and $\mathrm{SO}_{4}$, from the dissolution of carbonate, gypsum, and anhydrite. The hot spring waters in the Simao Basin are mixtures of $6 \%-42 \%$ deep thermal groundwater and 58\%-94\% shallow cold waters.

Geothermometers are comprehensively used to evaluate deep reservoir temperatures. Cation geothermometers are not suitable for calculating the reservoir temperatures because all the spring water samples are not in equilibrium. The reservoir temperatures calculated with the quartz geothermometer are $51-127^{\circ} \mathrm{C}$, which are regarded as the minimum reservoir temperatures due to the effect of mixing. In order to eliminate the error of $\mathrm{Al}$ analysis and the effect of mixing, the fixed-Al diagram is used to restore the equilibrium, getting the reservoir temperatures ranging from $91^{\circ} \mathrm{C}$ to $132^{\circ} \mathrm{C}$.

In the Simao Basin, hot springs with varying temperature and TDS occur, respectively, in red beds and metamorphic rocks of relatively low permeability and carbonate rocks with karst and fissures. After receiving recharge from precipitation in the mountain areas, the groundwater undergoes deep circulation and is heated by heat flow and interacts with the surrounding rocks and rises along permeable fault or fracture zones and emerges in the form of hot springs.

\section{Data Availability}

The data used to support the findings of this study are included within the article.

\section{Conflicts of Interest}

The authors declare that they have no conflicts of interest.

\section{Acknowledgments}

This work was supported by the National Natural Science Foundation of China (41772261 and 41572223).

\section{References}

[1] D. Oyuntsetseg, D. Ganchimeg, A. Minjigmaa, A. Ueda, and M. Kusakabe, "Isotopic and chemical studies of hot and cold springs in western part of Khangai Mountain region, Mongolia, for geothermal exploration," Geothermics, vol. 53, pp. 488-497, 2015.

[2] Z. Xun, F. Bin, Z. Haiyan, L. Juan, and W. Ying, "Isotopes of deuterium and oxygen-18 in thermal groundwater in China," Environmental Geology, vol. 57, no. 8, pp. 1807-1814, 2009.

[3] P. Koeniger, M. Toll, and T. Himmelsbach, "Stable isotopes of precipitation and spring waters reveal an altitude effect in the Anti-Lebanon Mountains, Syria," Hydrological Processes, vol. 30, no. 16, pp. 2851-2860, 2016.

[4] R. L. Hershey, S. A. Mizell, and S. Earman, "Chemical and physical characteristics of springs discharging from regional flow systems of the carbonate-rock province of the Great Basin, western United States," Hydrogeology Journal, vol. 18, no. 4, pp. 1007-1026, 2010.

[5] M. Yaguchi, Y. Muramatsu, H. Chiba, F. Okumura, T. Ohba, and M. Yamamuro, "Hydrochemistry and isotopic characteristics of non-volcanic hot springs around the Miocene Kofu granitic complex surrounding the Kofu Basin in the South Fossa Magna region, central Honshu, Japan," Geochemical Journal, vol. 48, no. 4, pp. 345-356, 2014.

[6] Z. H. Pang and M. Reed, "Theoretical chemical thermometry on geothermal waters: problems and methods," Geochimica et Cosmochimica Acta, vol. 62, no. 6, pp. 1083-1091, 1998.

[7] R. Sonney and F. D. Vuataz, "Validation of chemical and isotopic geothermometers from low temperature deep fluids of Northern Switzerland," Proceedings World Geothermal Congress, vol. 14, no. 1423, pp. 1-12, 2010.

[8] R. O. Fournier, "Chemical geothermometers and mixing models for geothermal systems," Geothermics, vol. 5, no. 1-4, pp. 41-50, 1977.

[9] M. P. Asta, M. J. Gimeno, L. F. Auqué, J. Gómez, P. Acero, and P. Lapuente, "Hydrochemistry and geothermometrical modeling of low-temperature Panticosa geothermal system (Spain)," Journal of Volcanology and Geothermal Research, vol. 235-236, no. 8, pp. 84-95, 2012.

[10] M. O. Awaleh, F. B. Hoch, I. H. Kadieh et al., "The geothermal resources of the Republic of Djibouti - I: hydrogeochemistry of the Obock coastal hot springs," Journal of Geochemical Exploration, vol. 152, no. 44, pp. 54-66, 2015.

[11] M. Belhai, Y. Fujimitsu, J. Nishijima, and M. Bersi, "Hydrochemistry and gas geochemistry of the northeastern Algerian geothermal waters," Arabian Journal of Geosciences, vol. 10, no. $1,2017$.

[12] T. Chandrasekhar, A. Minissale, O. Vaselli, D. Chandrasekharam, and H. K. Singh, "Understanding the evolution of thermal fluids along the western continental margin of India using geochemical and boron isotope signatures," Geothermics, vol. 74, pp. 197-209, 2018.

[13] Y. S. Zhang, D. L. Gao, L. Shi, Y. Liu, X. Y. Zhang, and B. L. Li, "Hydrochemical Characteristics of Salt Spring and PotassiumProspecting Research in Mengla Salt-belts of Simao Basin, Yunnan," Journal of Salt Lake Research, vol. 21, no. 2, pp. 10-17, 2013.

[14] Y. Bo, C. Liu, Y. Zhao, and L. Wang, "Chemical and isotopic characteristics and origin of spring waters in the LanpingSimao Basin, Yunnan, Southwestern China," Chemie der Erde, vol. 75, no. 3, pp. 287-300, 2015. 
[15] Y. Q. Zhang, X. Zhou, H. S. Liu et al., "Hydrogeological characteristics of the hot springs and salty springs occurring in the redbeds in the Lanping-Simao Basin of Yunnan," Hydrogeology and Engineering Geology, vol. 45, no. 3, pp. 40-48, 2018.

[16] Yunnan Bureau of Geology and Mineral Resources, Geology of the Saline Deposits in Simao District, Geological Publishing House, Yunnan, Beijing, 1986.

[17] Yunnan Bureau of Geology and Mineral Resources, Regional Geology of Yunnan Province, Geological Publishing House, Beijing, 1990.

[18] Y. H. Qu, P. Q. Yuan, K. Y. Suai et al., "Potash- forming rules and prospect of lower tertiary in Lanping- Simao Basin," Geological Publishing House, Yunnan, Beijing, 1998.

[19] Yunnan Local Chronicle Compilation Committee, Hot Springs Records of Yunnan Province (Vol. 25), Yunnan People's Publishing House, Kunming, 1999.

[20] R. Karolyte, S. Serno, G. Johnson, and S. M. V. Gilfillan, “The influence of oxygen isotope exchange between $\mathrm{CO}_{2}$ and $\mathrm{H}_{2} \mathrm{O}$ in natural $\mathrm{CO}_{2}$-rich spring waters: implications for geothermometry," Applied Geochemistry, vol. 84, pp. 173-186, 2017.

[21] H. Craig, "Isotopic variations in meteoric waters," Science, vol. 133, no. 3465, pp. 1702-1703, 1961.

[22] X. P. Zhang, H. D. Guan, Z. A. Sun, G. L. Sun, X. Z. Zhang, and $\mathrm{H}$. W. Wu, "Simulations of stable isotopic variations in precipitation and comparison with measured values in Yunnan Province, China," Scientia Geographica Sinica, vol. 32, no. 1, pp. 121-128, 2012, in Chinese.

[23] M. Afsin, D. M. Allen, D. Kirste, U. G. Durukan, A. Gurel, and O. Oruc, "Mixing processes in hydrothermal spring systems and implications for interpreting geochemical data: a case study in the Cappadocia region of Turkey," Hydrogeology Journal, vol. 22, no. 1, pp. 7-23, 2014.

[24] W. Z. Gu, Z. H. Pang, Q. J. Wang, and X. F. Song, Isotope Hydrology, Science Press, Beijing, 2011, (in Chinese).

[25] R. J. Gibbs, "Mechanisms controlling world water chemistry," Science, vol. 170, no. 3962, pp. 1088-1090, 1970.

[26] C. A. J. Appelo and D. Postma, Geochemistry, Groundwater and Pollution, Balkema, Leiden, 2nd edition, 2005.

[27] W. M. Edmunds, A. H. Guendouz, A. Mamou, A. Moulla, P. Shand, and K. Zouari, "Groundwater evolution in the Continental Intercalaire aquifer of southern Algeria and Tunisia: trace element and isotopic indicators," Applied Geochemistry, vol. 18, no. 6, pp. 805-822, 2003.

[28] B. L. Mu, Element Geochemistry, Peking University Press, Beijing, 1999, (in Chinese).

[29] P. Y. Xu and Z. N. Ding, "Formation of potable natural mineral spring water containing strontium," Site Investigation Science and Technology, vol. 5, pp. 36-38, 1997, (in Chinese).

[30] D. L. Parkhurst and C. A. J. Appelo, "User's guide to PHREEQC (Version 2) : a computer program for speciation, batch-reaction, one-dimensional transport, and inverse geochemical calculations," Water-Resources Investigations Report, vol. 99-4259, p. 312, 1999.

[31] W. F. Giggenbach, "Geothermal solute equilibria. Derivation of Na-K-Mg-Ca geoindicators," Geochimica et Cosmochimica Acta, vol. 52, no. 12, pp. 2749-2765, 1988.

[32] J. Y. Wang, L. P. Xiong, and Z. H. Pang, Low-Medium Temperature Convective Geothermal System, Science Press, Beijing, 1993, in Chinese.
[33] Z. Mohammadi, R. Bagheri, and R. Jahanshahi, "Hydrogeochemistry and geothermometry of Changal thermal springs, Zagros region, Iran," Geothermics, vol. 39, no. 3, pp. $242-$ 249,2010

[34] M. Reed and N. Spycher, "Calculation of $\mathrm{pH}$ and mineral equilibria in hydrothermal waters with application to geothermometry and studies of boiling and dilution," Geochimica et Cosmochimica Acta, vol. 48, no. 7, pp. 1479-1492, 1984.

[35] J. O. Bjarnason, The Speciation Program WATCH, Version 2.1, Orkustofnun, Reykjavik, 1994.

[36] Z. Zhang, Z. Sun, and S. Wang, "Successful reconstruction the equilibrium status of Tanghu hot spring by using fixed-Al methods and it's meaningness," Journal of East China Geological Institute, vol. 26, no. 4, pp. 306-310, 2003, in Chinese.

[37] X. Zhou, X. M. Jin, S. H. Liang, Y. Shen, and H. M. Zhang, Special Topics on Groundwater Sciences, Geological Publishing House, Beijing, Second edition, 2017, (in Chinese).

[38] Q. Xu, J. A. Wang, J. Y. Wang, and W. R. Zhang, "Terrestrial heat flow and its tectonic significance in Yunnan, China," Geotectonica et Metallogenia, vol. 16, no. 3, pp. 285-299, 1992, in Chinese.

[39] R. O. Fournier and A. H. Truesdell, "Geochemical indicators of subsurface temperature-part 2, estimation of temperature and fraction of hot water mixed with cold water," Journal Research U. S. Geological Survey, vol. 2, no. 3, pp. 263-270, 1974.

[40] A. H. Truesdell and R. O. Fournier, "Procedure for estimating the temperature of a hot-water component in a mixed water by using a plot of dissolved silica versus enthalpy," Journal of Research of the U.S. Geological Survey, vol. 5, no. 1, pp. 49-52, 1977.

[41] S. Arnorsson, "Chemical equilibria in icelandic geothermal systems-Implications for chemical geothermometry investigations," Geothermics, vol. 12, no. 2-3, pp. 119-128, 1983.

[42] R. O. Fournier and A. H. Truesdell, "An empirical Na-K-Ca geothermometer for natural waters," Geochimica et Cosmochimica Acta, vol. 37, no. 5, pp. 1255-1275, 1973.

[43] S. P. Verma and E. Santoyo, "New improved equations for, and $\mathrm{SiO} 2$ geothermometers by outlier detection and rejection," Journal of Volcanology and Geothermal Research, vol. 79, no. 1-2, pp. 9-23, 1997. 

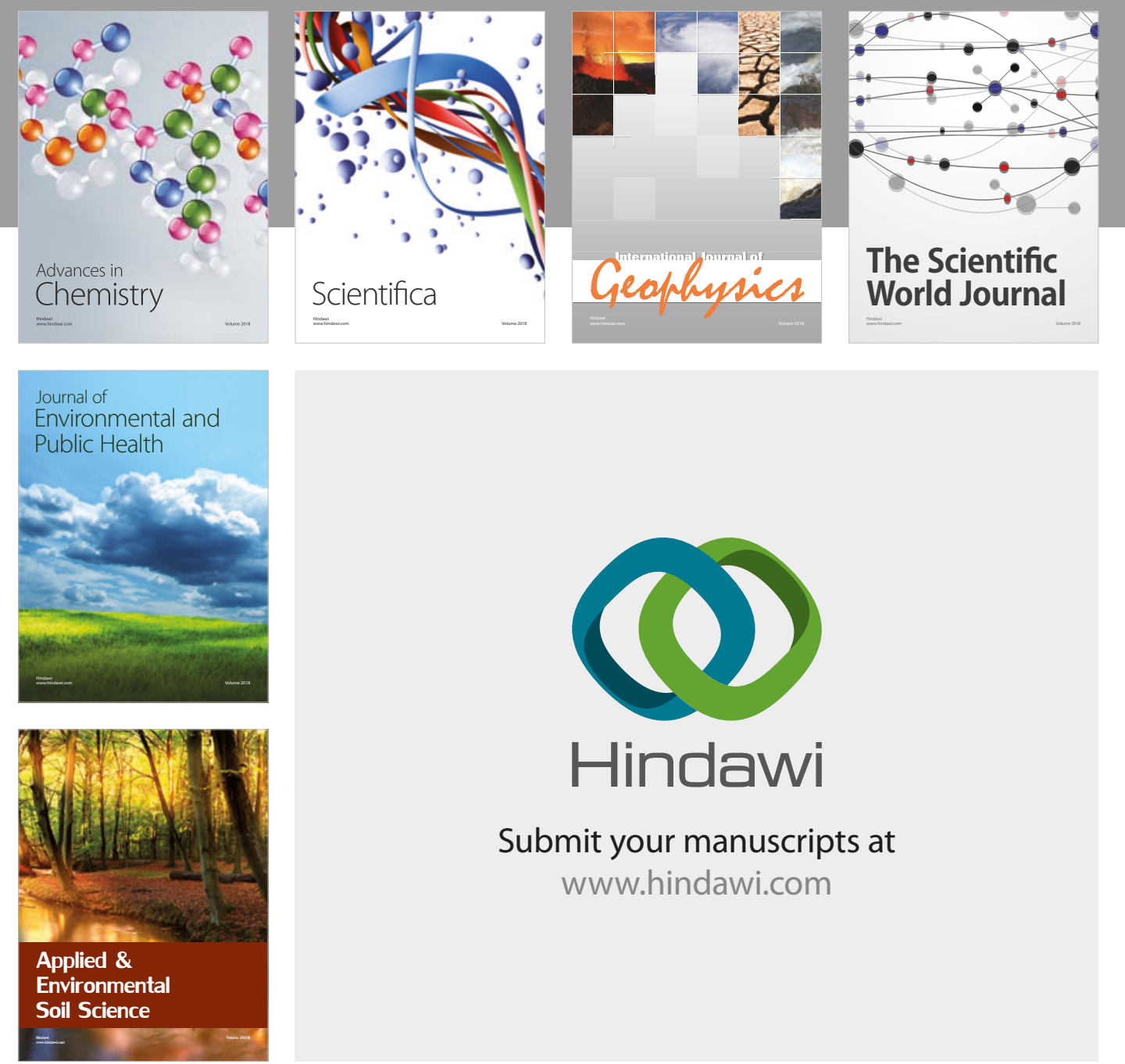

The Scientific

\section{World Journal}
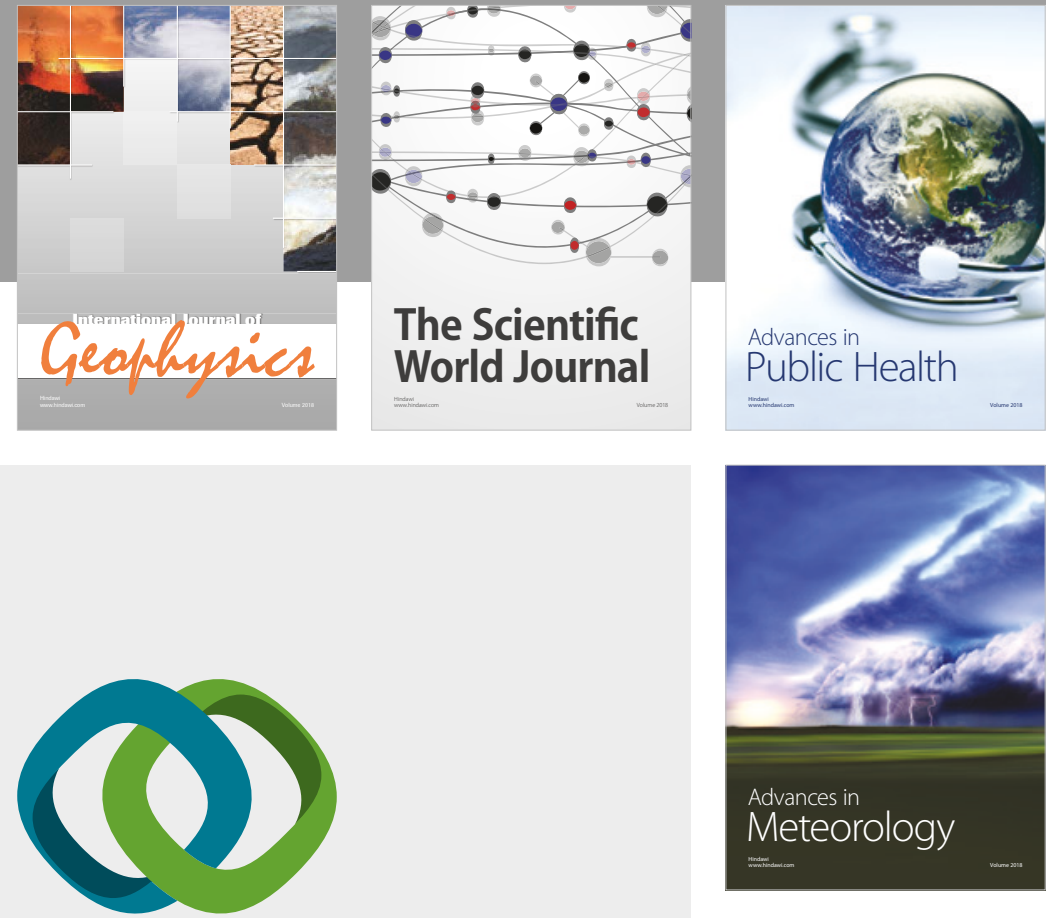

Advan

Public Health

\section{Hindawi}

Submit your manuscripts at

www.hindawi.com
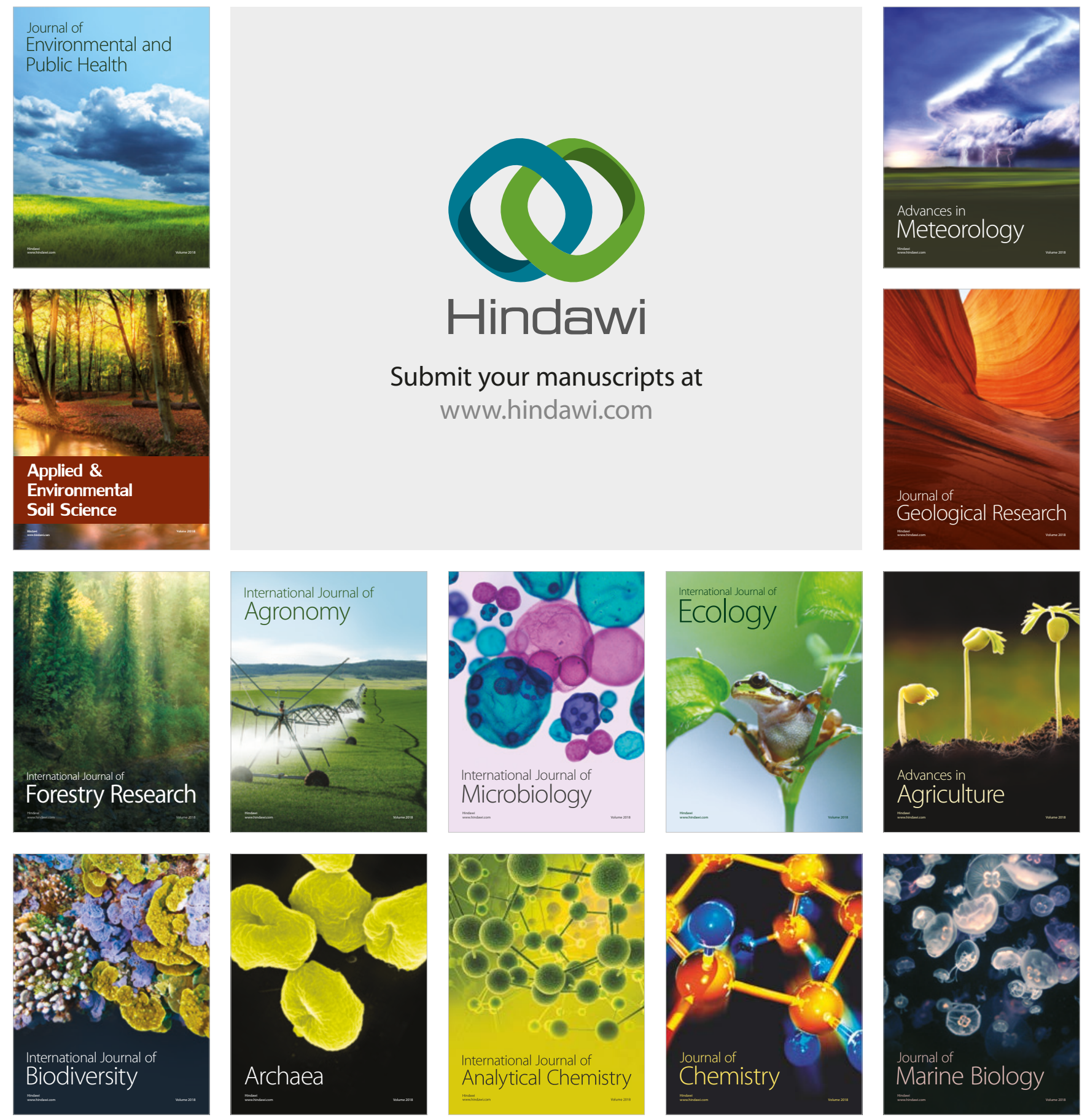